TECHNICAL NOTES AND MANUALS

\title{
Medium-Term Debt Management Strategy: Analytical Tool Manual
}

Emre Balibek, Tobias Haque, Diego Rivetti, and Miriam Tamene

Monetary and Capital Markets Department, International Monetary Fund

The World Bank

I NTERNATIONAL MONETARY FUND

$$
\text { THE WORLD BAN K }
$$


TECHNICAL NOTES AND MANUALS

Medium-Term Debt Management Strategy: Analytical Tool Manual

Emre Balibek, Tobias Hague, Diego Rivetti, and Miriam Tamene Monetary and Capital Markets Department, International Monetary Fund The World Bank

INTERNATIONAL MONETARY FUND THE WORLD BA N K

CInternational Monetary Fund. Not for Redistribution 


\title{
INTERNATIONAL MONETARY FUND
}

\author{
Monetary and Capital Markets Department
}

\author{
THE WORLD BANK
}

\section{Medium-Term Debt Management Strategy: Analytical Tool Manual}

Prepared by Emre Balibek, Tobias Haque, Diego Rivetti, and Miriam Tamene Authorized for distribution by Tobias Adrian and Ceyla Pazarbasioglu

February 2019

DISCLAIMER: This Technical Guidance Note should not be reported as representing the views of the IMF. The views expressed in this paper are those of the author(s) and do not necessarily represent the views of the IMF and the World Bank, their Executive Boards, or management.

\begin{tabular}{|l|l|}
\hline JEL Classification Numbers: & H600, H630, H680 \\
\hline Keywords: & $\begin{array}{l}\text { MTDS, Debt Management Strategy, Debt } \\
\text { Management, Debt Portfolio Cost and Risk Analysis }\end{array}$ \\
\hline Authors' E-Mail Addresses: & $\begin{array}{l}\text { mtamene@imf.org; ebalibek@imf.org; } \\
\text { thaque2@worldbank.org; } \text { drivetti@worldbank.org }\end{array}$ \\
\hline
\end{tabular}




\section{TECHNICAL NOTES AND MANUALS}

\section{Medium-Term Debt Management Strategy: Analytical Tool Manual}

This manual provides guidance on using the Analytical Tool of the Medium-Term Debt Management Strategy. 


\section{TABLE OF CONTENTS}

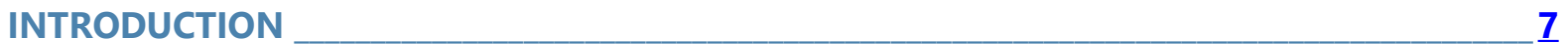

OVERVIEW OF THE ANALYTICAL TOOL________________________________

2.1 Types of Inputs ____

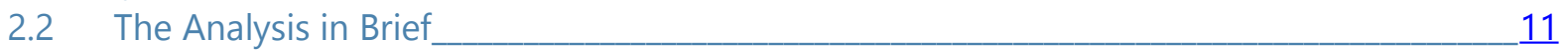

2.3 Synopsis of Outputs ________ 12

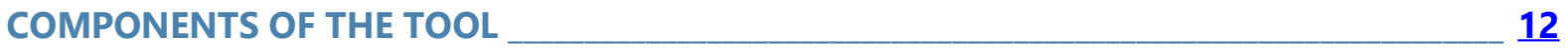

3.1 Inputs______ 12

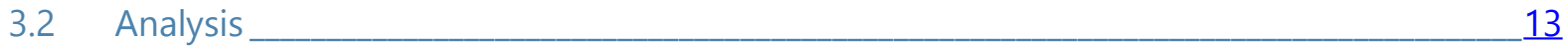

3.3 Outputs____ 14

THE ANALYTICAL TOOL: MODUS OPERANDI ___

4.1 Process Steps and General Guidance ________ 15

4.2 The "Existing Debt" Worksheet _____ 17

4.3 The "Macro and Market Data" Worksheet ________ 22

4.4 The "Strategy" Worksheet________ 25

4.5 The Output Worksheets______ 28

4.6 The "Risk Indicators" Worksheet____ 29

4.7 The "Redemption" Worksheets ____ 29

4.8 The "Strategy 1—4" Worksheets________

4.9 The "New Debt (Original Currency)" Worksheet ______ 30

4.10 The "New Debt (Domestic Currency)" Worksheet _____ 31

4.11 The "Total Debt" Worksheet ______ 31

\section{BOXES}

1. The MTDS AT and the DSA ________ $\underline{9}$

2. Coloring Coding Guides the Appropriate Use of Cells__________ 17

3. Using Instrument 1 and 20 for Other Instruments ___ 19

4. Calculation of Present Value______ 20

5. Specify Currencies for All Instruments _______ $\underline{20}$

6. Exchange Rates_____ 21

7. Interest Rates: Reference Rates and Spreads ____ 22

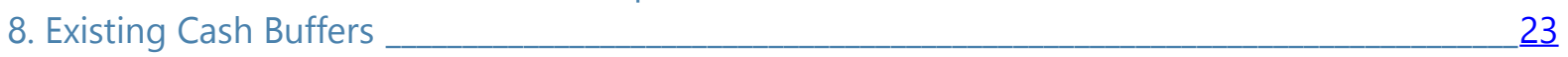

9. Exchange Rate Shocks______ 24

10. Interest Rate Shocks ____ 25

11. Ten Years of Interest Rate Projects_______ 25

12. Enable Excel Macros to Run the Tool_____ 28

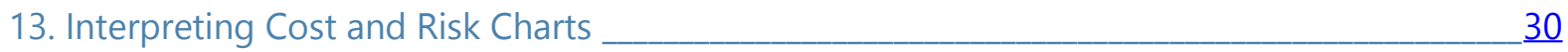

\section{FIGURES}

1. Overview of Analytical Tool ____________ 10

2. Possible Combination of Scenarios ______ $\underline{13}$

3. Sheets of the MTDS AT_____ 16 


\section{ANNEXES}

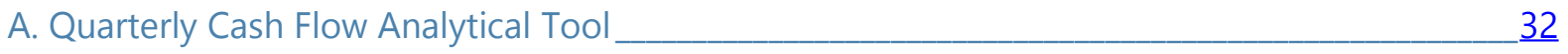

B. A Summary of Main Changes ______ 34

C. Non-Budgetary Funding Sources_____

D. Non-Budgetary Expenses ___

E. Strategies with Known Loan Disbursements_____

F. Strategies with Quantitative Restrictions ________ 41

G. Using a Single Instrument for Residual Financing ________

H. Incorporating Liability Management Operations_______ 47

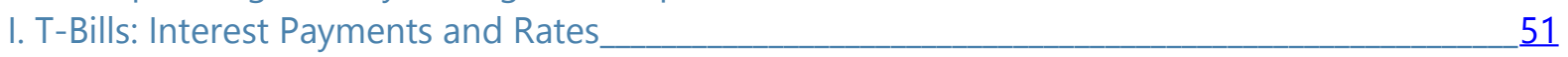

J. Debt Denominated in Special Drawing Rights ______ 54

K. Projecting Exchange Rate _______ $\underline{57}$

L. Building a Domestic Yield Curve______ 59

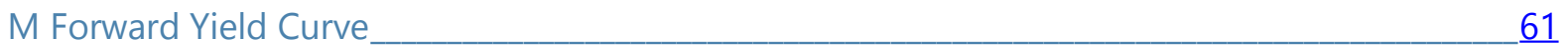

N. Formulae Used in the MTDS AT_______ $\underline{63}$

O. Excel Macros and Functions Used in the MTDS AT_____ 67 


\section{GLOSSARY}

\begin{tabular}{ll} 
AfDF & African Development Fund \\
AT & Analytical Tool \\
ATM & Average Time to Maturity \\
ATR & Average Time to Re-fixing \\
CNY & Chinese Yuan \\
DMS & Debt Management Strategy \\
DSA & Debt Sustainability Analysis \\
DSF & Debt Sustainability Framework \\
DX & Domestic currency \\
EUR & Euro \\
GBP & British pounds \\
GDP & Gross Domestic Product \\
Fix & Fixed Rate \\
FX & Foreign currency \\
IMF & International Monetary Fund \\
JPY & Japanese yen \\
LIC-DSF & The Debt Sustainability framework for Low-income Countries \\
LMO & Liability Management Operations \\
MAC-DSA & Debt Sustainability Analysis for Market Access Countries Debt \\
MTDS & Medium-Term Debt Management Strategy \\
QAT & Quarterly Analytical Tool \\
SDR & Special Drawing Rights \\
T-Bills & Treasury Bills \\
Var & Variable Rate \\
WB & World Bank \\
\hline
\end{tabular}




\section{INTRODUCTION}

1. The primary aim of debt management is to raise the required amount of funding at the lowest possible cost over the medium to long run, consistent with a prudent degree of risk. A debt management strategy (DMS) is a plan for the evolution of the public debt portfolio that operationalizes the debt management objectives given the constraints, and specifically the government's preferences with regard to cost-risk trade-offs. A DMS is one guiding component of public debt management, which also involves tactical decisions, coordination with other public sector policies, communication and accountability, and operations. A DMS feeds into borrowing plans and the budgetary framework, and has macroeconomic implications, for example, for the balance of payments. Debt managers are responsible for ensuring that financing constraints do not lead to sharp reversals in fiscal policy or spikes in interest costs due to the realization of market or other risks, such as contingent liability risk. Thus, sound debt management contributes to increased macrofinancial stability, complementing prudent fiscal management and monetary policy implementation. Debt management contributes also to market and institutional development. ${ }^{1}$

2. The World Bank (WB) and International Monetary Fund (IMF) have developed a systematic and comprehensive framework to help countries in the process of developing a DMS. The Medium-Term Debt Management Strategy (MTDS) framework consists of a methodology, published as the "Guidance Note for Developing a Medium-Term Debt Management Strategy" (February 2009), ${ }^{2}$ and an associated analytical tool (AT) that can be used to assess the cost-risk trade-offs of alternative strategies to help identify the preferred strategy. ${ }^{3}$ The steps involved in designing a strategy are discussed in detail in the Guidance Note and are summarized below. Although these steps are presented in a specific sequence, the sequencing is only indicative. In practice, the distinction between each step will not be too clear, several steps may be undertaken simultaneously, or in a different order:

- Identify the objectives for public debt management and scope of the medium-term debt management strategy (MTDS) and MTDS analysis.

- Identify the current debt management strategy and analyze the cost and risk of the existing debt.

- Identify and analyze potential funding sources, including their cost and risk characteristics.

\footnotetext{
1 See World Bank and IMF. "The Medium-Term Debt Management Strategy: An Assessment of Recent Capacity Building", July 10, 2017.

2 World Bank and IMF. "Developing a Medium-Term Debt Management Strategy (MTDS)—Guidance Note for Country Authorities." February 24, 2009. An updated version is being published alongside this manual.

3 This manual describes the MTDS Analytical Tool based on annual cash flow. The discussion is also applicable for the analytical tool that is based on quarterly cash flow. Differences between the two versions are described in Annex A.
} 
- Identify baseline projections and risks in key policy areas-fiscal, monetary, external, and market.

- Review key longer-term structural factors.

- Assess and rank alternative strategies on the basis of the cost-risk trade-off.

- Review implications of candidate debt management strategies with fiscal and monetary policy authorities, and for market conditions.

- Submit and secure agreement on the debt management strategy.

3. The AT is used to conduct quantitative analysis of alternative borrowing strategies by assessing them on the basis of the cost-risk trade-off; that is, it is used to carry out step 6 of the MTDS framework outlined above by utilizing information collected through steps 1 to 5 . However, in selecting the appropriate strategy the results of the quantitative analysis should not be the sole determinants. Essential qualitative factors, which are not captured in the AT, would need to be considered (for example, focus on domestic market development). Rather, the AT should be used to complement qualitative analysis, inform decision makers on the cost-risk trade-offs between viable financing strategies, and provide the cost-risk characteristics of the preferred strategy.

4. This manual introduces the reader on how to use the MTDS AT; it is meant to be used in conjunction with the AT, a Microsoft Excel-based model. ${ }^{4}$

${ }^{4}$ A description of the main changes compared to the previous version of this Manual, MTDS Analytical Tool, User Guide, May 2012, can be found at Annex B. 


\section{OVERVIEW OF THE ANALYTICAL TOOL}

5. The AT is used to assess and compare cost and risk characteristics of potential debt management strategies. Debt management strategies are different combinations of new borrowing across a range of debt instruments with varied financial characteristics designed to meet gross financing needs over a certain period. ${ }^{5}$ The AT allows the user to observe how the choice of strategy (that is, different composition of debt instruments) will influence the debt portfolio over a strategy period and assess how the costs of different strategies would change under different assumptions of interest and exchange rates.

6. The MTDS framework, and specifically the AT, should not be used to analyze debt sustainability. Officials concerned with debt sustainability should instead use the appropriate debt sustainability analysis (DSA) tool, Box $1 .{ }^{6}$

\section{Box 1. The MTDS AT and the DSA}

The MTDS framework supported by the AT quantitative analysis helps to determine the financing strategy. The chosen debt management strategy sets out the financing composition path to meet the debt management objective(s). The profile of future interest payments and the amortizations of new debt (as determined by the selected financing instruments) are driven by the debt management strategy.

Assessment of debt sustainability is made using a DSA tool. The DSA incorporates(a) fiscal policy assumptions underlying the country's fiscal framework, (b) the existing debt profile, and (c) future financing assumptions (as determined by the debt management strategy) to assess whether the country's debt level is sustainable over the long term. Based on the output from DSA, fiscal policy makers and debt managers may revise the fiscal framework and the financing strategy.

Interest payments and amortizations of the debt management strategy should feed into the DSA. While choices between borrowing strategies as informed by the MTDS AT may have some impact on debt sustainability ratios, primary deficit or existing debt levels are typically the main drivers of overall debt levels and ratios. Shocks required for undertaking debt sustainability analysis are not included in the MTDS AT. This reflects the standard role of the debt managers in identifying financing strategies to meet a given financing requirement, rather than determining the size of fiscal gap and the debt level. That said, to the extent that financing strategies shape the future debt structure, debt managers should assist fiscal authorities by identifying strategies with interest costs and repayment profiles consistent with fiscal sustainability.

\footnotetext{
${ }^{5}$ The AT allows the user to use a maximum of 20 types of debt instruments (see section 4.2). This requires the user to aggregate individual loans and debt securities into twenty stylized debt instruments based on their financial characteristics. Please refer to the manual on debt data preparation for instructions on debt data aggregation.

${ }^{6}$ Depending on the income category, either the Debt Sustainability Framework for Low-income Debt Sustainability, LIC-DSF, developed by the IMF and World Bank, or the Fund's Debt Sustainability Analysis for Market Access Countries, MAC DSA, should be utilized.
} 
7. The AT has three main components: (i) inputs; (ii) analysis; and (iii) outputs (Figure 1).

Figure 1. Overview of Analytical Tool

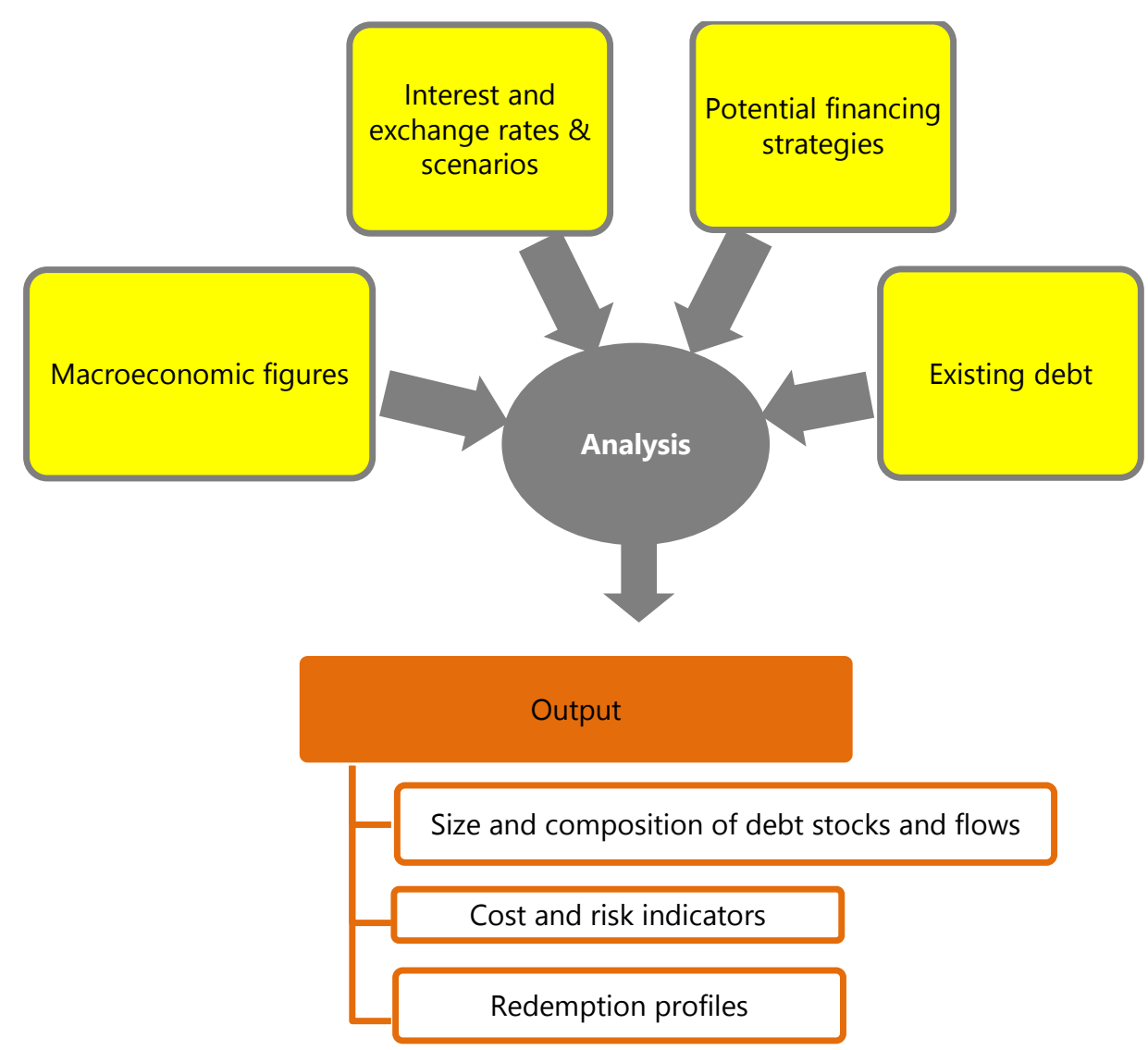

\subsection{Types of Inputs}

8. Four types of inputs are used in the AT:

- Data on existing debt is divided into principal and interest payments cash flows. This information is used to calculate cost and risk indicators of the debt portfolio at the start of the analysis period, and over the strategy period including new debt. ${ }^{7}$

- Fiscal aggregates together with debt service payments determine the overall amount of financing required. The primary deficit is calculated as the difference between revenue and primary expenditure (which are exogenous to the model). Forecasts of both revenues and primary expenditures over the whole strategy period are required. Total financing needs are calculated through the addition of interest payments and debt amortization to the primary deficit. Future interest payments and

\footnotetext{
${ }^{7}$ Unless the debt portfolio in its entirety consists of very short-term debt, some existing debt will still be outstanding at the end of the strategy period.
} 
debt amortization are calculated within the model as they vary according to the composition and terms of debt instruments used.

- Borrowing strategies determine how future financing needs will be met. Strategies are presented as the proportion of the financing need that will be met through a set of different stylized debt instruments (see $₫ 60 . \quad$ ). ${ }^{8}$ The terms (borrowing rates and amortization) of the different types of stylized debt instrument are specified to allow the AT to calculate debt service (principal and interest payment) over the strategy period. The model starts by calculating the interest and amortization cash flows associated with alternative strategies in the first year, which is then fed back into calculation of the total gross financing need for the following year. Based on specified strategy for the second year, interest and amortization cash flow are calculated to determine the third-year gross financing need, and so on. This iteration is repeated until the end of the strategy period. These strategies determine how the composition of the debt portfolio will change over the strategy period, allowing the generation of cost and risk indicators, including redemption profiles.

- Interest and exchange rate assumptions are entered into the model as exogenous variables. The user is required to enter both a baseline scenario and a range of shock scenarios for each variable. These are used to compute the cost and risk of borrowing debt strategies under different scenarios. Interest rates (baseline and shock) on cash buffers are also entered as exogenous variables. ${ }^{9}$

\subsection{The Analysis in Brief}

9. The AT uses the following process to combine the various inputs in order to produce outputs.

- Calculate debt cash flows under a given financing strategy and baseline interest and exchange rate assumptions. New borrowing under a given strategy (which meets gross financing needs) is aggregated with the data from the existing debt portfolio to determine the characteristics of the total debt portfolio during the analysis period. The cash flows, debt stocks, and risk indicators for the total debt portfolio are calculated under a specific debt management strategy. Resulting cash flows are saved as an output for this strategy (for example, Strategy 1 under baseline pricing assumption). Total financing needs and the amount of borrowing will automatically be adjusted to reflect interest and amortization under this strategy. Because the financing need in any given year includes interest payments and amortization, the financing need will change under different composition of new borrowing associated with different strategies.

- Calculate debt cash flows for the same financing strategy under shock scenarios. The process described above is repeated for a different exchange rate or interest rate

\footnotetext{
${ }^{8}$ In the MTDS framework, external loan/debt, refers to the currency denomination of the debt obligation and not to the residency classification of creditors.

${ }^{9}$ While the MTDS AT allows the consideration of cash buffers, this feature does not have to be used.
} 
scenario. Changes in projected cash flows under the different assumptions drive changes in total financing needs and the level of borrowing. The result for total debt is saved as an output for the same strategy under a specific stress test (for example, Strategy 1 under currency depreciation assumption). Similarly, the debt levels, cash flows, and cost-risk indicators under additional different interest rate and exchange rate assumptions are calculated and the results saved in the same worksheet.

- Calculate debt cash flows under different strategies. The process and calculation above is repeated for all four strategies (that is, Strategy 2, 3, and 4), which comprise different combinations of borrowing instruments under the same baseline and shocks. Up to four strategies are examined, and outputs are saved (cash flows and cost-risk indicators).

- Combinations of borrowing strategies (4) and market rate scenarios (5) are calculated and $20(4 * 5)$ sets of complete future cash flows are calculated and saved.

\subsection{Synopsis of Outputs}

10. Outputs of the model allow the user to compare potential debt management strategies, based on the costs and risks of the resulting debt portfolios and cash flows.

11. The output of the AT presents debt levels and standard debt portfolio risk exposure indicators under the four strategies. This allows the user to compare among potential borrowing strategies, taking account of associated costs and risks. The user can assess how different strategies perform in managing or reducing risks that are of particular importance.

12. Comparisons of the cost of different strategies are also presented under both the baseline (cost) and the most-extreme shock scenario (maximum risk). These outputs allow the comparison of different strategies taking account of the fact that the lowest cost strategy may differ under various interest and exchange rate assumptions, and vary across cost definitions.

\section{COMPONENTS OF THE TOOL}

13. The AT, which is an Excel-based model, is fairly simple and transparent; all steps and formulas are visible and can be easily followed and interpreted by the user. As described above, the AT calculates basic cost and risk indicators for different combinations of debt strategies and interest and exchange rate assumptions, stores the output, and show comparisons between these outputs. An Excel Macro function is used to automate the simulation (the repetitive copying and pasting of results that is required for comparison of outputs from different combinations of strategies and scenarios). The inputs, the analysis, and the outputs of the AT are described below.

\subsection{Inputs}

14. Input data is entered into three separate worksheets; these are identified by yellow tabs. The current debt portfolio data is entered in the Existing Debt worksheet. Debt data is entered in summary form through the use of stylized debt instruments. Stylized debt instruments capture 
the key financial features of loans and securities (for example, maturity, grace period, currency, interest rate). ${ }^{10}$ The tool allows the use of 20 stylized debt instruments, including existing debt and any new borrowing instruments that the user may introduce. Note that the 20 available instruments cover both existing and new instruments.

15. Macroeconomic projections, which contribute to the calculation of the total financing need, are entered as input into the Macro and Market Data worksheet. Data on projected interest and exchange rates under baseline and shock scenarios are also entered into this worksheet.

16. Financing strategies and cash buffers are specified in the Strategy worksheet, with the user selecting: (i) the external-domestic mix of new financing over the analysis period; (ii) the composition of both new external and domestic financing from a range of stylized debt instruments; and (iii) the option to add cash buffers (that is, the option not to utilize (spend) all funding raised in the same year or use existing cash buffer that was available at the start of the strategy period).

\subsection{Analysis}

17. When the AT is run, the Excel Macro selects a set of market inputs (for example, the baseline exchange and interest rates), a single strategy from the four alternative choices available, and cash buffer targets, and applies the selections in the appropriate places.

18. Through the application of standard Excel functions and cash flow formulas, the AT then calculates the total cash flows for that given strategy under the baseline and shock exchange rate and interest rate scenarios. ${ }^{11}$ Cash flows from new borrowing during the strategy period are calculated within new debt worksheets, while cash flows of existing debt are calculated within the Existing Debt worksheet. ${ }^{12}$ The cash flows of existing and new debt are combined in the Total Debt worksheet. The Excel Macro saves the output from the Total Debt worksheet in the relevant strategy sheet (for example, in worksheet Strategy 1). The output in each of the strategy worksheets, for example Strategy 1, is the full cash flow information for the given strategy under the baseline and shock scenario assumptions, taking into account any cash buffer assumptions.

19. From this point, the AT repeats the calculations for the other three strategies under baseline and shock scenarios. Overall, the Excel Macro will calculate 20 combinations of borrowing strategy and macro-market scenario (Figure 2). Cash flows for every combination are saved in the respective Strategy worksheets (Strategy 1, Strategy 2, Strategy 3, and Strategy 4). These worksheets are hidden by default, but can be unhidden using Macro buttons from the

\footnotetext{
${ }^{10}$ For example, domestic securities with bullet repayment and fixed interest rate, with original maturities of 9 to 12 years could be represented with stylized debt instrument of 10 years, grace period of 9 years and applying the weighted average yield rate. For further detail on aggregation of debt data please refer to the "Medium-Term Debt Management Strategy Analytical Tool: Data Preparation Manual".

11 The standard Excel Functions used in the AT are CONCATENATE, HLOOKUP, IF, LEFT, MAX, MIN, RIGHT, SUMIF, SUMPRODUCT, and VLOOKUP.

12 There are two new debt worksheets, as the name of the worksheet implies, the first shows calculation of new debt in original currency, New_Debt (Original Currency), and the second shows the new debt in local currency, New_Debt (Domestic Currency).
} 
READ ME worksheet. After running the AT the individual strategy worksheets (Strategy $\mathbf{1}$,

Strategy 2, Strategy 3, and Strategy 4), and the calculation worksheets (New Debt (Original Currency), New Debt (Domestic Currency), and Total Debt) will become unhidden; should the user wish to hide these again the hide and unhide Excel-Macros found in the READ ME worksheet can be used.

Figure 2. Possible Combination of Scenarios
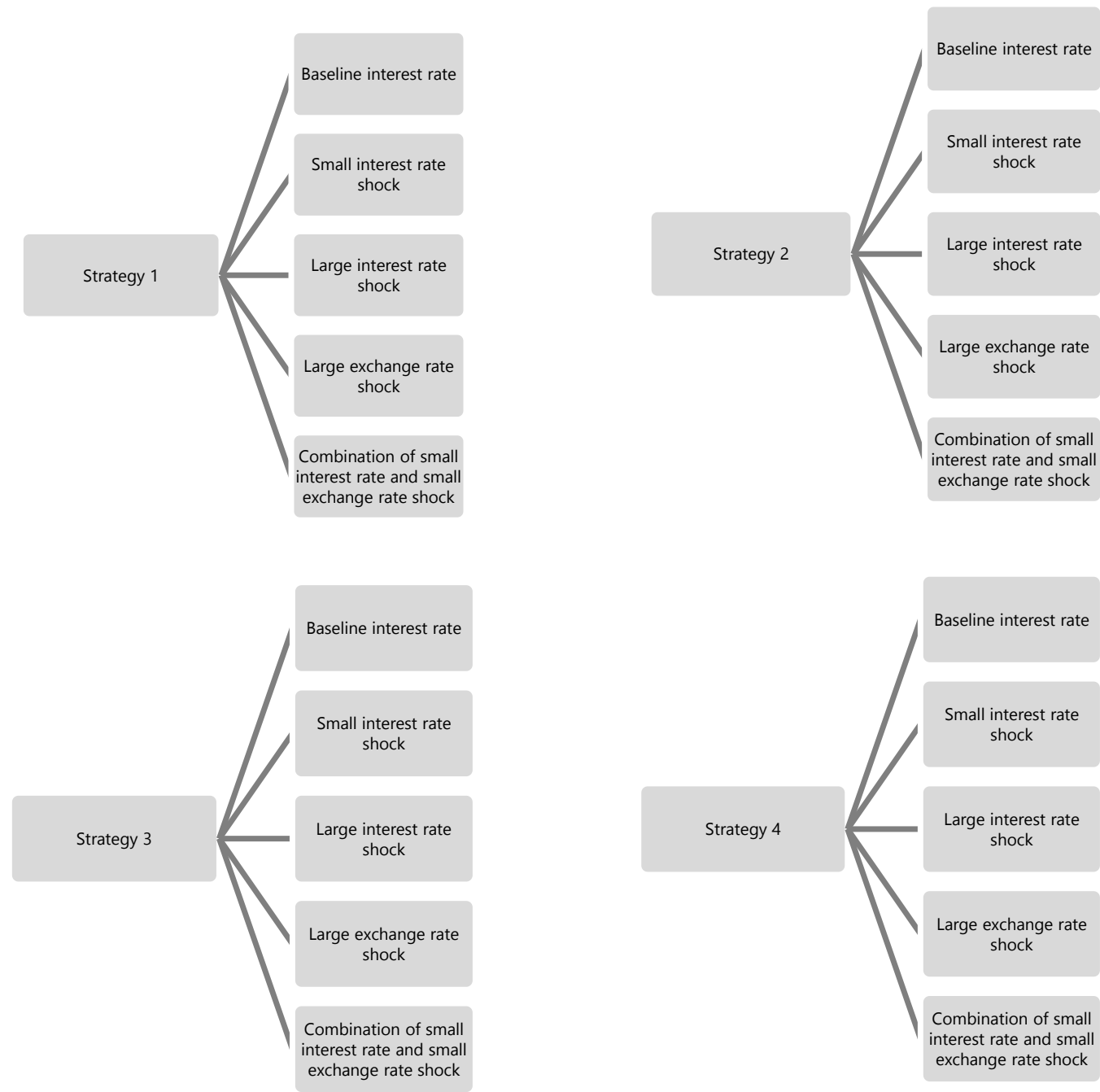

\subsection{Outputs}

20. In the Summary Results, Tables, Charts, Risk Indicators, and Redemption worksheets, key variables are calculated from cash-flows saved from the different strategies, and presented for easy comparison. Pricing assumptions are depicted in Pricing worksheet.

21. The Summary Results worksheet depicts key outputs of the AT regarding the cost and risk indicators, which can also be also found in more detail in the following sheets. 
22. The Tables worksheet presents key variables for debt stocks and flows, and standard risk indicators at the end of the strategy period, as well as each year in the strategy period. It also shows how modeled shocks would impact the cost of debt under different strategies.

23. The Charts worksheet depicts the cost-risk results from the strategy simulations; it presents the results in the Tables worksheet in the form of charts.

24. The Risk Indicators worksheet displays the cost and risk indicators for all strategies under baseline scenarios at the end of the strategy period. Information is organized both by strategy and by risk indicators to facilitate easy comparison.

25. The Redemption worksheets present redemption profiles at the end of each year of the strategy period for every strategy, presented by currency and interest type.

\section{THE ANALYTICAL TOOL: MODUS OPERANDI}

26. This section provides a guidance on utilizing the AT. General guidance is provided before the use and purpose of key worksheets is described in detail.

\subsection{Process Steps and General Guidance}

27. Running the AT requires the following steps:

- Enter all required information into input worksheets.

- Run the strategies by pressing the 'Run all strategies' button in the Strategy worksheet.

- Evaluate the output tables and charts.

- If the user wishes to make adjustments to a specific strategy (either affecting the external-domestic financing mix or the distribution within domestic or external instruments) or make any change to other data (existing debt, macro, or financialbaseline or shock scenario), enter the new required inputs and rerun the Excel Macro by pressing "Run all strategies".

28. The worksheets used in the AT, their color coding (Box 2), and a brief description of their purpose are shown in Figure 3. Worksheets are ordered from left to right within the AT, beginning with guidance worksheets that include, READ ME Instructions List of Outputs and Input Area Visual Maps. The latter two worksheets are hidden by default, but can be unhidden using Macro buttons from the READ ME worksheet. The user is strongly advised to read the green colored worksheets before starting to use the AT. 


\begin{tabular}{|c|c|c|}
\hline \multicolumn{3}{|c|}{ Figure 3. Sheets of the MTDS AT } \\
\hline Worksheet Name & Category & Purpose \\
\hline READ ME & \multirow{4}{*}{ Instructions } & $\begin{array}{l}\text { Provides important information and guidance to the AT, including color } \\
\text { coding rules, and all automated Excel Macro. }\end{array}$ \\
\hline Instructions & & $\begin{array}{l}\text { Includes instructions, references to data input areas, and key MUST Do's } \\
\text { and Don'ts. }\end{array}$ \\
\hline List of Outputs & & $\begin{array}{l}\text { Provides a list of outputs with references to the "Table", "Charts", and "Risk } \\
\text { Indicators" worksheets }\end{array}$ \\
\hline Input Area Visual Maps & & $\begin{array}{l}\text { Provides a glance, through embedded pictures, of input areas in the AT for } \\
\text { a quick reference and checks. }\end{array}$ \\
\hline Existing Debt & \multirow{3}{*}{ Inputs } & $\begin{array}{l}\text { Country and currencies, units of currency, strategy period, starting year of } \\
\text { analysis, stylized instruments for existing and new debt, and existing debt } \\
\text { data are entered in this worksheet. The worksheet includes debt service } \\
\text { cash flows of existing debt portfolio. }\end{array}$ \\
\hline Macro and Market Data & & $\begin{array}{l}\text { Worksheet to input the macroeconomic framework and exchange and } \\
\text { interest rate assumptions. There is also an empty space for the user that } \\
\text { can be used to incorporate further analysis and/or assumptions. }\end{array}$ \\
\hline Strategy & & $\begin{array}{l}\text { To input strategies defined in terms of the proportion of financing needs to } \\
\text { be met from different stylized instruments, cash buffer targets, and } \\
\text { operational targets. }\end{array}$ \\
\hline $\begin{array}{l}\text { Summary Results } \\
\text { Tables } \\
\text { Charts } \\
\text { Pricina }\end{array}$ & \multirow{3}{*}{ Outputs } & $\begin{array}{l}\text { Presentation of debt stocks and flows and cost and risk indicators for all } \\
\text { strategies and scenarios at the end of the forecast period. Pricing } \\
\text { assumptions are also represented as charts in a separate worksheet. }\end{array}$ \\
\hline Risk Indicators & & $\begin{array}{l}\text { Presentation of debt stocks and flows and cost and risk indicators for all } \\
\text { strategies under baseline scenario year by year for all indicators. The } \\
\text { exceptions are indicators that use the entire cashflow until maturity (for } \\
\text { example, Average Time to Maturity) where the indicators are provided at } \\
\text { the end of the simulation period. }\end{array}$ \\
\hline $\begin{array}{l}\text { Redemption by FX-DX and } \\
\text { interest type }\end{array}$ & & Presentation of redemption profiles over the strategy period. \\
\hline Strategy $1,2,3, \& 4$ & Results & $\begin{array}{l}\text { Saved output of cash flows for each strategy under baseline and shock } \\
\text { scenarios. }\end{array}$ \\
\hline $\begin{array}{l}\text { New Debt } \\
\text { (Original Currency) }\end{array}$ & \multirow{3}{*}{ Analyses } & $\begin{array}{l}\text { Used by the Excel Macro to calculate new debt cash flows under each } \\
\text { strategy and baseline and shock assumptions in original currency. }\end{array}$ \\
\hline $\begin{array}{l}\text { New Debt } \\
\text { (Domestic Currency) }\end{array}$ & & $\begin{array}{l}\text { Used to convert output from the New Debt (Original Currency) worksheet } \\
\text { into domestic currency. }\end{array}$ \\
\hline Total Debt & & Sum of existing debt and new debt cash flows. \\
\hline
\end{tabular}




\subsection{The "Existing Debt" Worksheet}

29. The Existing Debt worksheet contains five sections: (i) Key Parameters \& Instruments;

(ii) Cost Risk Indicators for Existing Debt; (iii) Existing Debt Cash Flow from Database; (iv) Existing Debt Cash Flow in Original Currency; and (v) Existing Debt Cash Flow in Domestic Currency.

\section{Box 2. Coloring Coding Guides the Appropriate Use of Cells}

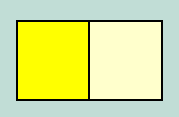

All bright yellow cells have to be filled in or updated. Cells in pale yellow can be used to enter additional working data and calculations. Information entered into pale yellow cells will not be automatically picked up by the AT, nor disrupt its functioning. Cells that are not colored in either bright or pale yellow contain formulas or are otherwise used by the model and therefore should not be edited or overwritten.

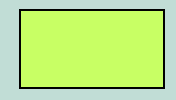

Green cells are used to denote consistency checks.

Purple cells are used for copying and pasting values by the Excel Macro. Alternative financing strategies, as well as baseline assumptions and stress tests scenarios for exchange rates and interest rates are copied into these cells. They should not be used by the user to store information as running the Excel Macro will overwrite any information.

Grey cells include formulas or are areas used by the model that must not be changed by the user.

\subsubsection{Key Parameters and Instruments}

\section{Key Parameters}

30. Key parameters are entered into the area $A 6: B 14$. The user specifies a time horizon for the MTDS from the drop-down menu in cell B6. ${ }^{13}$ The template can accommodate up to 10 years of strategy period. Debt data should be the latest available at the end of fiscal or calendar year; this is the debt data cut-off date, for example, December 31, 2017. Ideally this should coincide with the latest fiscal outturn used for the medium-term expenditure planning. The year of the cut-off date is the base year for the analysis, and the year that immediately follows will be the start year of the analysis. The user needs to specify whether the analysis will be on fiscal or calendar years, enter the base year, country name, the domestic currency code, the units for debt data (that is, millions, billions), and specify whether the existing debt data input is in foreign or local currency. The choice of local or foreign currency for the existing debt will not affect any of the output.

\section{Stylized Instruments}

31. Names and parameters of the stylized instruments to be used are entered into the area C7:J26. Stylized instruments are used to represent the financing terms and model the cash flows of either: (i) debt instruments in the existing portfolio that will continue to be used over the strategy period; and (ii) new debt instruments the user may consider utilizing over the strategy period. The MTDS AT allows for a maximum of 20 stylized debt instruments. In compiling data,

\footnotetext{
${ }^{13}$ As the strategy period is entered, a message pops up that requires the user to confirm that the strategy period has changed. The user should click ok; this action will shade yellow all required input areas in the AT.
} 
users should refer to Government Finance Statistics Manual 2014, which provides guidance on financial assets and liabilities. Loans and securities are relevant liabilities for MTDS purposes. Assets include both financial assets (for example, government's equity in an enterprise) and nonfinancial assets (for example, state-owned enterprises), where their sale results in cash proceeds that can then be used to reduce financing requirements.

32. Two stylized instruments have specific assignments: Instrument 1 is assigned to the African Development Fund (AfDF), which has a unique principal repayment profile. Instrument 20 is assigned to indexed instruments that allows the principal amount to be adjusted by the relevant reference rates (see Box 3). ${ }^{14}$ There is no minimum for the number of instruments that can be used, and countries with relatively simple debt portfolios may only need to use a small number of instruments.

33. The design of Instrument 20 can be applied to other instruments, if countries borrow in many indexed instruments (for example, inflation, GDP, commodity price-l inked bonds). However, users should note that the tool does not take into account second-round effects. For example, for an instrument linked to oil price, a decline in oil price would mean lower debt service for that instrument. While the AT would capture the debt service adjustment, provided the reference rates (in the exchange rate area) reflect the reduction in oil price, the wider macroeconomic effects from lower oil price, which may in turn have implications for primary balance, are not incorporated.

34. More broadly, the tool does not endogenize borrowing instruments in response to firstround effect. However, users can compare the differences in debt service only, that is, with no feedback loop to macro assumptions, by using the same instruments in two identical strategies under different market rate assumptions. ${ }^{15}$

35. Instruments such as Sukuk and Green Bonds can be modeled as conventional bonds; since their cost and risk characteristics are comparable to them, as far as exposure to market rates are concerned..$^{16}$ Debt-for-nature swaps are akin to liability management operations, whereby the transaction changes the underlying debt portfolio.

\footnotetext{
${ }^{14}$ Countries with inflation adjusted principal indexed instruments should choose "Var" from the drop-down menu for interest type, and enter the real interest rate projections as credit spread in the Marco and Market Data worksheet (E154: O154), leaving the reference rates empty (E131:0131). The reference rates should instead be entered in the exchange rate depreciation area, cells F85:085. For indexed instruments, where the reference rates apply to the coupon only and not the principal, then reference rates should be entered in the reference row (E131:0131) leaving the exchange rate depreciation area, cells F85:O85, empty.

15 However, users can mimic second-round effects by using similar instruments with different market rates. For example, create two representative instruments, five-year bullet bonds, labelling one UTP_5YR_A (normal conditions) and the other UTP_5YR_B (adverse conditions); enter interest rate assumptions to reflect the secondround effect under UTP_5YR_B; for example, a sharp rise in the yield curve in the second or third year. Finally, set up two strategies identical in all but these for instruments, where each is used in one and the other. By comparing the results, one can assess the effects of second-round effects.

${ }^{16}$ For example, the special features of Green bonds are related to the use of the proceeds from issuance of such instruments as opposed to the instruments themselves. In the case of Sukuk, the cash-flows are generated by the underlying assets, unlike conventional bond. However, the actual cash-flow to the final investor follow the same structure; their return can be fixed or variable rate like coupons on conventional bonds.
} 


\section{Box 3. Using Instrument 1 and 20 for Other Instruments}

The first stylized instrument, Instrument 1 , is restricted by default to instruments with financing features similar to the AfDF; the color is white as opposed to yellow to reflect the fact that parameters are not changeable. The MTDS AT applies a pre-defined unconventional amortization profile to reflect AfDF loans' stepped-up amortization profile. The last stylized instrument, Instrument 20, allows the principal amount to be adjusted by reference rates. For example, for inflation adjusted principal instruments, the principal is adjusted by inflation which is then used to calculate the interest payments and the principal repayment. If a country has indexed instrument where the indexation applies to the coupon only, then by using reference interest area and the risk spread area, the indexation to coupon only is applied. If a country does not have debt with similar features to AfDF loans or indexed linked bonds, then Instruments 1 and 20 should not be used.

Alternatively, if the user wishes to use these two instruments for a different type of stylized instrument, the following adjustments need to be made. For Instrument 1 the formula for principal repayment should be modified to eliminate the special feature by deleting * $30 * 2 \%$ cell by cell in the column F 37 to F46 in the New Debt (Original currency) worksheet, and copying the revised formula in F37:F46 across from column G through BM. For Instrument 20, the user can simply override the currency code IDX in the Existing Debt worksheet (cell J26), and enter the relevant codes and the exchange rate in cells L11 and $\mathrm{M} 11$, respectively, in the same worksheet. In addition, cell F177 should be amended so that it equals to $\mathrm{F} 131+\mathrm{F} 154+\mathrm{F} 201$ and this formula should be copied across to BM177.

36. Instruments' identifier and financing terms (currency, grace period, and final maturity) must be entered by the user. For variable rate instruments, use code "Var", for fixed rate instruments, use code "Fix", and for Treasury Bills, use T-bills. ${ }^{17}$ The user must also specify whether a discount rate should be applied when calculating the present value of instruments. This is achieved by selecting 'yes' or 'no' from the dropdown menu in cells F7 to F26 (Box 4). For domestic-currency denominated debt instruments use the code in cell B11, and for foreigncurrency denominated debt instruments use the appropriate codes entered in cells L7: L10; the tool will fill corresponding cells in column I, by identifying local currency debt as "DX" and the rest as "FX" for foreign currency. In addition, all the cells in J7:J26 need to be populated even if there are no corresponding debt instruments (Box 5).

\footnotetext{
17 While all T-bills are treated as a one-year discounted instruments, such identification provides better information in the cost-risk analysis outputs and redemption profiles. For those countries that rely heavily on T-bills, particularly those with maturities of less or equal to six months, it is recommended that they use the quarterly version the Analytical Tool (Annex A).
} 


\section{Box 4. Calculation of Present Value}

The tool allows the user to apply discount rates to debt instruments. This function can be used to assess the concessionality of the representative instrument and calculate the present value of debt service repayments. While such calculations are similar to those undertaken in the context of LIC-DSF, the model user is highly encouraged to use the LIC-DSF template for the purpose of evaluating debt sustainability, and the grant element calculator provided by the Fund to assess the concessionality of individual loans. ${ }^{1}$ Figures derived by the MTDS tool will differ from those generated by:

- the LIC-DSF template for a number of reasons including the definition and scope of debt, and

- the grant element calculator since the characteristics of individual loans will differ from those stylized instruments used the MTDS.

With this in mind, borrowing from non-official creditors (such as debt securities, retail debt, and bank loans), which are priced at market rates, should be assumed to have no concessionality and therefore should not be discounted. ${ }^{2}$ On the other hand, those loans contracted from the official sector-both bilateral and multilateral-should be discounted to assess the degree of concessionality, since such loans are normally priced below market rates and have long maturities, giving rise to substantive concessionality.

The discount rate is set by default at 5 percent in line with the discount rate used in the LIC-DSF. ${ }^{2}$

1/ Follow this URL for grant element calculator http://www.imf.org/external/np/spr/2015/conc/index.htm.m

2/ Under the current low interest rate environment debt securities and loans may carry concessionality, but this has more to do with the discount rate used ( 5 percent) rather than the features of the instruments. Therefore, in line with the underlying principle, those instruments contracted at market rates should not be discounted https://www.imf.org/external/np/sec/pr/2013/pr13408.htm.

\section{Box 5. Specify Currencies for All Instruments}

Specify currencies for unused instruments. Even if the user is not modelling the effect of all 20 instruments, cells $\mathrm{J} 7$ to $\mathrm{J} 26$ should be filled with arbitrary currency codes (for example, USD, UTP). This avoids problems with lookup functions used extensively in the MTDS AT.

\section{Exchange Rates (at the end of Base Year)}

37. Exchange rate information is added in the area L7:M10, and L12:M12, with each stylized instrument also assigned a currency in cells J7:J25. The MTDS AT allows for up to four foreign currencies-one foreign base currency (typically USD or EUR) and three other foreign currencies-and the domestic currency (identified in the cells M12). ${ }^{18}$ The currency codes must consist of three letters. Exchange rates are initially expressed in units of foreign or domestic currency per base currency (cells M8 to M10, and M12), while the base currency exchange rate is always ' 1 ' (cell M7). ${ }^{19}$ Exchange rates in units of domestic currency per unit foreign currency are

\footnotetext{
18 If the existing debt portfolio has more currencies than programmed in this template, then the user needs to assign them to one of the six main currencies during the data preparation exercise. Loans in Special Drawing Rights (SDRs) will also need to be converted into one or a combination of the four foreign currencies (Annex J).

${ }^{19}$ Note that the exchange rate for indexed instrument (cell M11) is set to equal domestic currency (cell M12).
} 
calculated by the AT (cells N7 to N12). Future exchange rates are derived based on assumptions on depreciation or appreciation vis-à-vis base rates (Box 6).

\section{Box 6. Exchange Rates}

Exchange rates in area M7:M10, and M12 should be as of the end of the base year. These exchange rates are used to derive future exchange rates by applying projected rates of depreciation or appreciation to the base rate. The projected rates of depreciation or appreciation projections are entered in the Macro and Market Data worksheet.

\subsubsection{Cost Risk Indicators of Existing Debt}

38. In this section, the MTDS AT calculates the cost-risk indicators for the existing debt stock, at the end of the base year, based on data on the existing debt portfolio. A redemption profile from cash flows on the existing debt as at the end of the base year is also presented. This information can be used to analyze the existing debt portfolio and identification of risks.

\subsubsection{Existing Debt Cash Flow from Database}

39. The user inputs data on the existing debt portfolio, aggregated into up to 20 stylized instruments, in millions of base currency units (note that aggregation of existing debt can be in foreign or local currency, 131). The following information for the existing debt stock has to be entered:

- Projections of principal payments (up to maturity) are entered in cells F55:BM74.

- Projections of interest payments: full projected interest payments on fixed-rate debt should be included, for variable interest rate debt the interest payments arising only from the spread component of the relevant interest rate should be included (see Box 7). Interest payments are entered in cells F101:BM120. For T-bills imputed interest payments in the first year should be entered. ${ }^{20}$

- Debt outstanding at the end of the base year are calculated in area E78:E97.

40. The above data (debt outstanding, principal repayments, and interest payments) for the stylized instruments must be prepared outside the MTDS AT, through aggregation of the original loan by loan data extracted from the debt database. ${ }^{21}$

\footnotetext{
20 See Annex I for guidance on capturing the accurate interest payments and calculating the weighted average annualized yield for T-bills.

21 See separate manual 'Data Preparation Manual' for guidance on aggregation of debt data. Please note that external debt/financing in the context of MTDS refers to currency as opposed to residency definition (see footnote 8).
} 


\section{Box 7. Interest Rates: Reference Rates and Spreads}

Interest payments of debt with variable and fixed interest rates should be calculated differently when preparing data for the MTDS AT.

For debts with fixed interest rate, interest payments are calculated by taking the outstanding amount of debt of the previous period and multiplying that by the fixed interest rate. For debts with variable interest rate, the interest rate usually has two components:

- a fixed element, which is commonly referred to as "a spread," and

- a variable element, which is commonly referred to as "a reference rate."

As part of preparing existing debt data for the MTDS AT, each annual interest payment on debt with a variable interest rate should be calculated by multiplying the debt outstanding of the previous year by the spread only. The results are then entered into the interest payments part of Existing Debt worksheet.

Since reference rates tend to change periodically, the user will estimate future reference rates and enter them in Macro and Market Data worksheet. The AT will apply these rates to the debt outstanding and add the results to those interest payments, calculated using the spread element, in Existing Debt worksheet to derive the total amount of interest payments.

\subsubsection{Existing Debt Cash Flow in Original Currency}

41. In this section, the MTDS AT reports cash flows in the currency assigned to the instrument by applying the exchange rates at the end of the base year, as specified in the Existing Debt worksheet (L7:L12). Interest payments for fixed rate debt are simply converted using the end of base year exchange rates. Interest payments for floating-rate instruments are computed by combing the spread-based figures from the data in the previous section with the market reference interest rates in the Macro and Market Data worksheet.

\subsubsection{Existing Debt Cash Flow in Domestic Currency}

42. In this section, the MTDS AT reports cash flows presented in the section immediately above, converted into domestic currency using exchange rate projections based on the projected depreciation rates in Macro and Market Data worksheet, area F81:086; the actual exchange rates projections are in area E92:BM97.

\subsection{The "Macro and Market Data" Worksheet}

43. The Macro and Market Data worksheet consists of two sections: (i) macroeconomic (fiscal) information; and (ii) market rates, which in turn includes two sub-sections, exchange rates and interest rate projections.

44. In this worksheet, the user specifies the macroeconomic scenario and baseline pricing assumptions as well as the shock scenarios with alternative assumptions. Shock scenarios permit testing the robustness of each financing strategy to adverse market conditions (for example, exchange rate depreciation greater than that envisaged under the baseline scenario, interest rates higher than those assumed under the baseline scenario). 


\subsubsection{Macroeconomic Information}

45. In this section, the AT calculates the total gross financing needs. The user enters the baseline medium-term macro-framework in the yellow cells in area E4:Q5, E7:Q9, E15:Q21, E27:Q33 and cell E36 (Box 8). The baseline macro-fiscal framework could be taken, for example, from the latest budget projections prepared by the unit in the Ministry of Finance responsible for fiscal forecasting. In some situations, there could be sources of financing (for example, deposits, proceeds from asset sales, E15:Q17 with the applicable probability E19:Q21) or expenses (for example, contingent liabilities, arrears clearance, E27:Q29, and applicable probability E31:Q33) that could arise that are not captured in the budget figures of revenue and expenditure, respectively. The user is advised to make use of this area to enter all available information. Please see Annex $C$ and $D$ for illustrations on how to incorporate such data. ${ }^{22}$

46. Blank rows (in pale yellow: E38:Q50) are available for the user to enter, for example, for entering additional budgetary or macroeconomic information, sources of information for fiscal numbers, or for additional analysis. The AT does not use figures entered in this area.

\section{Box 8. Existing Cash Buffers}

In some cases, there could be cash buffers set aside for debt management purposes. The level of the cash buffer available at the start of the strategy period should be entered in cell E36 in local currency. The user should not use this cell to enter any other item, as this is linked to cash buffer targets in the strategy period (\$62).

In cases where the existing cash buffer is in foreign currency, its value should be converted into local currency. If the existing cash buffer is not available immediately, that is, if it is set aside for use in future years then, users should place it under "non-budgetary assets section" to ensure that existing cash buffers are used in the desired year.

47. The MTDS AT calculates the three variables underlying the gross financing needs that are key for the borrowing strategies. These variables are: (i) the primary deficit, calculated as the difference between the public sector primary expenditure and total revenue (including grants); (ii) the interest payments on the existing debt and the new debt issued going forward; and (iii) the principal payments on the existing debt and the new debt issued going forward. The gross financing needs are the sum of these three variables.

48. While the financial characteristics of existing debt and primary deficit are exogenous to the tool, interest and principal payments of new debt are endogenously generated based on the borrowing strategy and the scenarios for exchange and interest rates. For instance, the domestic currency value of the principal and interest payments corresponding to the existing and new external debt depends on the projections made for exchange and interest rates. Loan contracts typically stipulate the currency of repayments, and the domestic currency value of those will be

\footnotetext{
${ }^{22}$ Inputs in area E7:Q9 (budgeted interest payments, international reserves, and GDP) are not necessary for generating cash flow projections, but are used to compare outputs with current expectations (for example, to gauge the difference in interest payments under the selected strategy versus the budget), or to calculate cost-risk ratios (for example, debt-to-GDP).
} 
dependent on the exchange rate. The principal and interest payments corresponding to the new debt issued going forward depends on the borrowing strategy and the market scenario.

\subsubsection{Market Rates}

\section{Exchange Rate Projections}

49. In the exchange rate projections section, the user should enter the assumptions about exchange rate depreciation/appreciation under the baseline and under two shock scenarios (which are in addition to the baseline appreciation/depreciation) (Box 9). ${ }^{23}$ The baseline exchange rate assumptions are entered in cells F81:086 and expressed as percentage changes from the base exchange rate entered into the Existing Debt worksheet ( $(37)$. A positive number implies a nominal depreciation of the domestic currency against the foreign currency, whereas a negative number implies nominal appreciation. The derived exchange rates based on the depreciation/appreciation assumptions are calculated (F92: BM97).

50. The AT allows the user to specify the percentage change against each currency under two shock scenarios, and the years the shocks are to be applied. The years for the first and second shock are specified in cells R81:R86 and AF81:AF86, respectively. The percentage depreciation/appreciation under each shock are specified in cells S81:S86 and AG81:AG86, respectively.

51. The Excel Macro copies the three scenarios into the range F101:0106 (purple cells) when computing combinations of strategies and scenarios. The exchange rates thus obtained, reported in range E92:BM97, are expressed in units of domestic currency.

\section{Box 9. Exchange Rate Shocks}

Exchange rate changes specified under both the baseline and shock scenarios are percentage changes to the base year exchange rate provided in the Existing Debt worksheet (cells: L7:M12 in Existing Debt sheet). A percentage change entered to determine a shock in a given year is therefore sustained into the future as a one-off but permanent nominal appreciation or depreciation that is not reversed. Shocks are added to the percentage changes in the baseline, so the underlying trend specified in the baseline will be maintained.

Note that the base period exchange rate is an end-of-period rate, which is what is relevant for measuring end-year stocks. The exchange rate that applies to debt servicing payments that take place in the course of the year may differ from the end-of-year effect. This difference in valuation, which is small if the exchange rate is relatively stable, is ignored here for the sake of simplicity.

\section{Interest Rate Projections}

52. In the interest rate projections section, the user should enter the assumptions for interest rates under the baseline and two shock scenarios (Box 10). The interest rate is computed as the sum of (i) the reference interest rate (for example, for U.S. Libor rate), and (ii) the risk spread

\footnotetext{
23 The second shock (30 percent by default) is the only foreign exchange rate (FX) shock that is reported as a stand-alone shock. The first shock (by default 15 percent) is simulated in a combination with moderate interest rate shock.
} 
representing the premium the borrowing country would have to pay above the U.S. Libor rate. When the Excel Macro is running shock scenarios, the third component of the interest rate-a shock that equals zero under the baseline or a positive value under the two shock scenarios-is also added.

53. In addition to each representative instrument, interest rate assumptions for cash buffers, if applicable, would also need to be entered in cells F205:O206 for baseline, and F211:0212 for shock scenarios.

\section{Box 10. Interest Rate Shocks}

Different interest rate shocks can be specified for different instruments. Importantly, interest rate shocks can also be specified in ways that reflect different movements of the yield curve or changes in interest rate spreads from reference rates. For example, movements at the short end of the yield curve can be adjusted by changing the interest rate shock for shorter-term instruments while leaving the shock rates for longer-term instruments unchanged (or changed by lower amount). Parallel shifts of the yield curve or a change in risk spreads that apply across instruments can be adjusted by changing the interest rate shocks on relevant instruments of all maturities.

It is important to note that the AT assumes that all new disbursements against fixed-rate instruments will be subject to the applicable interest rate at the time of disbursement. For instruments where most of the new disbursements will carry interest rates that have already been specified in contracts, the interest rate should not change over the forecast period.

54. The Excel Macro adds the reference, spread, and additional shock components of the interest rates and pastes the result into the range F182:0201 (purple cells) when computing combinations of strategies and scenarios. The interest rates thus obtained, reported in range E158:BM177, are expressed as percentages. Interest rate projections beyond the strategy period are assumed to be held constant as the last year of projection (Box 11).

\section{Box 11. Ten Years of Interest Rate Projects}

It is essential to enter values for the reference interest-rate and the risk spread for a period of 10 years, in addition to the base year, regardless of the projection horizon of the strategy. For strategies with a period of less than 10 years, it can be assumed that interest rates will remain the same as the last year of the strategy period for the remaining years. This is needed so that cash flows are calculated until the longest maturing debt is repaid. Interest rate for the periods beyond the $11^{\text {th }}$ year is assumed to remain at the same rate as in year 10 .

\subsection{The "Strategy" Worksheet}

55. In the Strategy worksheet, the user defines the four alternative financing strategies that could satisfy the gross borrowing requirement. A strategy defines the proportion of the total gross financing need to be met from each of the 20 stylized debt instruments in each year of the projection period.

56. Strategies are defined in three stages. First, an 'operational target' is defined in row 29 of the Strategy worksheet. The operational target allows the user to define how much of the total gross financing need will be met from external and domestic sources. Second, the user 
determines the specific instrument mix that will be used for external and domestic financing needs respectively. Third, cash buffer targets at the end of each year during the strategy will have to be specified in units of local currency, if the strategy envisages cash buffers. Otherwise, row 30 should be left empty. These steps are shown in Figure 4 and described in turn.

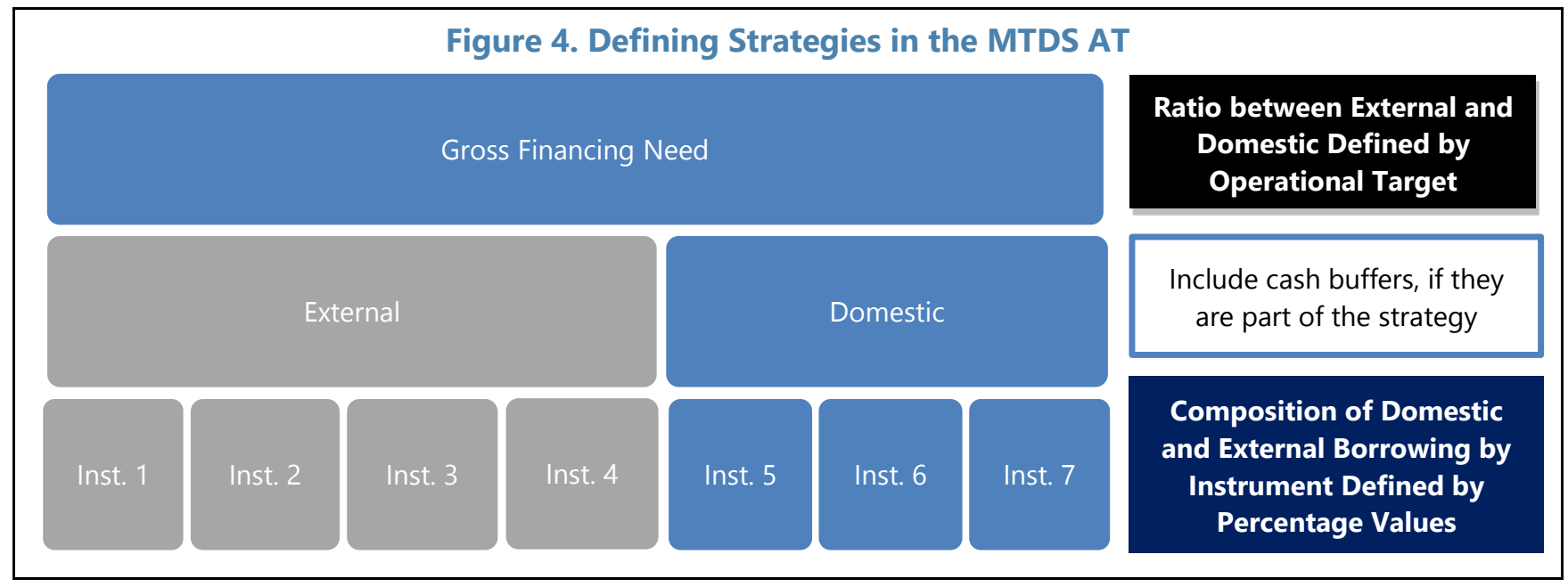

\subsubsection{Operational Targets}

57. The operational target determines the external-domestic financing mix for each strategy. The user must first choose a definition for the operational target. Options for defining the operational target are available from the dropdown menu in cells O29, AB29, AO29, and BB29. Those options are:

- External borrowing as a fraction of gross borrowing requirement;

- Net domestic financing as percentage of GDP;

- Net domestic financing in millions of local currency; and

- Gross external borrowing in millions of base currency unit.

58. After choosing the definition of the operational target, the user must choose values for this operational target for all years of the strategy. These values are entered as percentages or millions of currency units (depending on how the target is defined) in the cells immediately to the right of the operational target dropdown menu.

59. Once a quantity or ratio for external or domestic financing is chosen, the amount of financing from the other option is calculated as the residual. For example, if the operational target determines that 50 percent of gross borrowing requirements will be met from external sources, the other 50 percent will be met from domestic sources.

\subsubsection{Components of External and Domestic Borrowing}

60. Once the user has selected the operational target, the second step is to determine the fraction of the borrowing that will be made in the different instruments. This is defined in cells Q56:Z75 for Strategy 1. Simple percentages are used to distribute the gross financing need 
across instruments. Because both domestic and external financing needs have to be fully met, the sum of domestic instruments and the sum of external instruments should both be 100 percent, with a sum of 200 percent for all instruments.

61. Since the percentage entered in cells Q56:Z75 is expressed in terms of domestic borrowing, these are converted to percentage of the total borrowing by multiplying the external instrument proportions by the share of total external in total borrowing (Q52), and the domestic instrument proportions with the share of total domestic in total borrowing (Q53). This is automatically calculated and is reported in range Q6:Z25 (for Strategy 1). The respective areas for Strategy 2, AB56: AM75, Strategy 3, AO56:AZ75, and Strategy 4, BB56: BM75, should be filled out in similar manner. The Excel Macro copies the four strategies into the range D6:M25 (purple cells) one by one in combination with the various scenarios and save the results in the individual strategy worksheets, Strategy 1 Strategy 2 Strategy 3 , and Strategy 4.

\subsubsection{Cash Buffers}

62. The user has the option to build cash buffers from new borrowing starting in the first year of analysis, by setting cash buffer targets for each of the years in the strategy period. The cash buffers are then available for drawdown in subsequent years. They can be used to reduce gross financing or buy back debt instruments. The primary purpose is to allow the user the option of saving (putting aside), proceeds from new borrowing (for example, large international bond issuance) for future use. ${ }^{24}$ Cash buffers are entered in local currency and in the units specified in the Existing Debt worksheet (cells B11 and B12), in the case of Utopia for example, in millions of UTP. Cash buffers for Strategy 1, 2, 3, and 4 should be entered in Q30:Z0, AD30:AM30, AQ30:AZ30, and BD30:BM30, respectively. The existing cash buffer the start of the strategy period should be entered in cell E36 of the Macro and Market Data worksheet. The net borrowing requirement for the cash buffer for the first year, in the strategy period, is the difference between the target and the existing level. For subsequent years, this is determined by the differences between cash buffer targets.

\subsubsection{Additional Considerations in Determining Borrowing Strategies}

\section{Quantitative Borrowing Restrictions}

63. At times, future disbursement amounts from some creditors are known (for example, from multilateral institutions). When such disbursements are applicable, the user may wish to use the working area available in Macro and Market Data worksheet to compute the percentages of borrowing for each instrument (Annex E).

64. In some cases, the user may wish to define one or more strategies in nominal values as opposed to percentages. This approach can be accomplished by running the model iteratively (Annex F).

\footnotetext{
24 Please note that any preexisting cash buffers should not be entered in this area. Instead they should be entered in cell E36 in Macro and Market Data worksheet (Box 8).
} 


\section{Liability Management Operations}

65. Liability management operations, namely, buyback and debt exchanges, can also be included in the strategy. The results can be compared with a similar strategy without LMOs, to inform decision making (Annex $\mathrm{H}$ ).

\subsubsection{Run the Model}

66. The Excel Macro that drives the AT is initiated from the Strategy worksheet; the user needs to enable the macro (Box 12). ${ }^{25}$ To run the AT the user should click on the button in cell A26/A28 "Run all strategies." This will run the model with the newly defined strategies under the baseline and alternative scenarios. ${ }^{26}$

\section{Box 12. Enable Excel Macros to Run the Tool}

To enable Excel Macros within Excel, choose the option to allow Excel Macros when Excel initially opens the AT. Alternatively, if Excel is already running the AT, go to File $>$ Options $>$ Trust Center $>$ Trust Center $>$ Trust Center Settings $>$ Macro Settings $>$ Enable All Macros.

\subsection{The Output Worksheets}

67. The MTDS AT calculates and displays cost-risk indicators for the borrowing strategies at the end of the projection horizon (up to ten years) and for each year of the analysis period. The Tables worksheet consists of five sections, with corresponding outputs in the Charts worksheet (for the selected strategy period): ${ }^{27}$ Some of the key outputs in these two worksheets are also presented in the Summary Results worksheet.

- The section on composition of existing debt and alternative strategies provides information on stocks and flows by instrument. It includes: (i) the proportion of new borrowing by instrument and strategy over the projection period; (ii) proportion of outstanding debt by instrument and strategy over the projection period; and (iii) gross and net borrowing in domestic and base currency and as a proportion of GDP by strategy and instrument.

- The cost-risk indicator table provides cost-risk indicators under the baseline scenario of the current portfolio, and each strategy at the end of the projection period. The table allows easy comparison between the current debt portfolio and that which would be achieved by the end of the projection period under different strategies, (Box 13).

\footnotetext{
25 In some versions of Excel, if the button does not work, the user may have to run the "Run_all_strategies" macro, reaching it from the "View" tab (View/Macros/View Macros) or the "Developer" tab (Developer/Macros).

${ }^{26}$ In addition, individual Excel Macro buttons are available for those wishing to run each strategy separately.

27 The user should ignore results beyond the strategy period.
} 
- Debt stock and composition of gross financing at the end of the analysis period for each strategy are displayed.

- The section on cost-risk indicators for baseline and shock scenarios displays a selection of cost and risk indicators as at the end of the projection period for use in comparing strategies. ${ }^{28}$

- Principal Repayment and Outstanding Debt Profile at the end of the strategy period are presented by external and domestic currency as well as interest type.

- The Annual Gross Borrowing Requirement, Net Borrowing, and Outstanding Debt section provides composition of gross borrowing requirement by financing sources (by instruments) for each strategy. Outstanding debt, overall deficit, and gross borrowing requirement by currency and in percent of GDP are also provided.

- Annual Cost-Risk Indicators for the baseline and shock scenarios are displayed for all strategies for the following indicators: debt to GDP, interest payment to GDP, present value of debt to GDP, debt service payment to GDP, and external debt service in millions of U.S. dollars (or the main base foreign currency). The cash-flow and timeseries tables and charts of cost indicators of each strategy can be useful in analyzing the evolution of headline debt ratios over the projection period.

68. The Pricing worksheet depicts the assumptions about exchange rates and interest rates.

\subsection{The "Risk Indicators" Worksheet}

69. The Risk Indicators worksheet provides year by year information regarding the evolution of the standard debt indicators for all strategies under the baseline scenario. The only exception is for those indicators that require the cashflow to maturity; for such indicators results are given at the end of strategy period. ${ }^{29}$ The worksheet is divided into two sections. Rows to 1:344 present all risk indicators organized by strategy. Rows further below are organized by cost-risk indicator to facilitate comparison of the same indicator between strategies.

\subsection{The "Redemption" Worksheets}

70. The Redemption worksheets present redemption profiles as at the end of every year of the forecast period for each strategy. This allows the user to review changes to the redemption

\footnotetext{
${ }^{28}$ Seven indicators are presented. Five indicators provide measures as percentages of GDP: nominal and present value of debt stock, external debt, debt service, and interest payments. The other two indicators are the percentage ratios of interest payments to revenue, and external debt service to international reserves.

29 To calculate risk indicators that require cash flow to maturity, such as average time to maturity, the debt portfolio at the end of each year in the strategy period need to be analyzed to exclude future cash flows from the same representative instruments (within the strategy period). If the user wishes to see how the cost-risk indicator is evolving through the strategy period, then the tool must be run starting with strategy period of 1 to the strategy period itself and saving the results separately. For example, if the strategy period is 4, then the user must run the tool with strategy period 1, save the result, then open a copy of the tool and run it with strategy period 2 , save the result, and so on until strategy period 4.
} 
profile over time under different strategies. Two separate sheets are available, organized by currency and interest types.

\section{Box 13. Interpreting Cost and Risk Charts}

Charts of cost-risk are presented in two types of charts, a scatter plot and stacked column bar, presenting the cost against risk of different strategies at the end of the financing period.

In the scatter plots charts the $y$-axis shows the cost of different strategies under the baseline scenario, whereas the $x$-axis shows risks, the difference in cost between the baseline and the most extreme shock scenario. Points further to the right on the $\mathrm{x}$-axis are associated with wider difference between costs under the baseline and most extreme shock scenario. However, wide difference does not necessarily mean that particular strategy would result in the highest cost under a shock scenario (compared with the other strategies). A strategy that is further to the right on the $x$-axis than other strategies but much lower on the $y$-axis may still represent a low-risk strategy relative to other strategies if the total costs under the most extreme shock scenario are low relative to costs under other strategies (that is, costs are still lower than other strategies under a 'worst case' scenario). The user must therefore interpret the $\mathrm{x}$-axis with care. Large difference should only be interpreted as higher risk if the difference is sufficient to change the ranking of the strategies when placed in order of cost.

Visually the stacked column bar charts found to the right of the scatter charts, which use the same data as the scatter plots, make such comparison easy to check. These charts show the baseline costs with the marginal additional cost under the most extreme cost scenario also added.
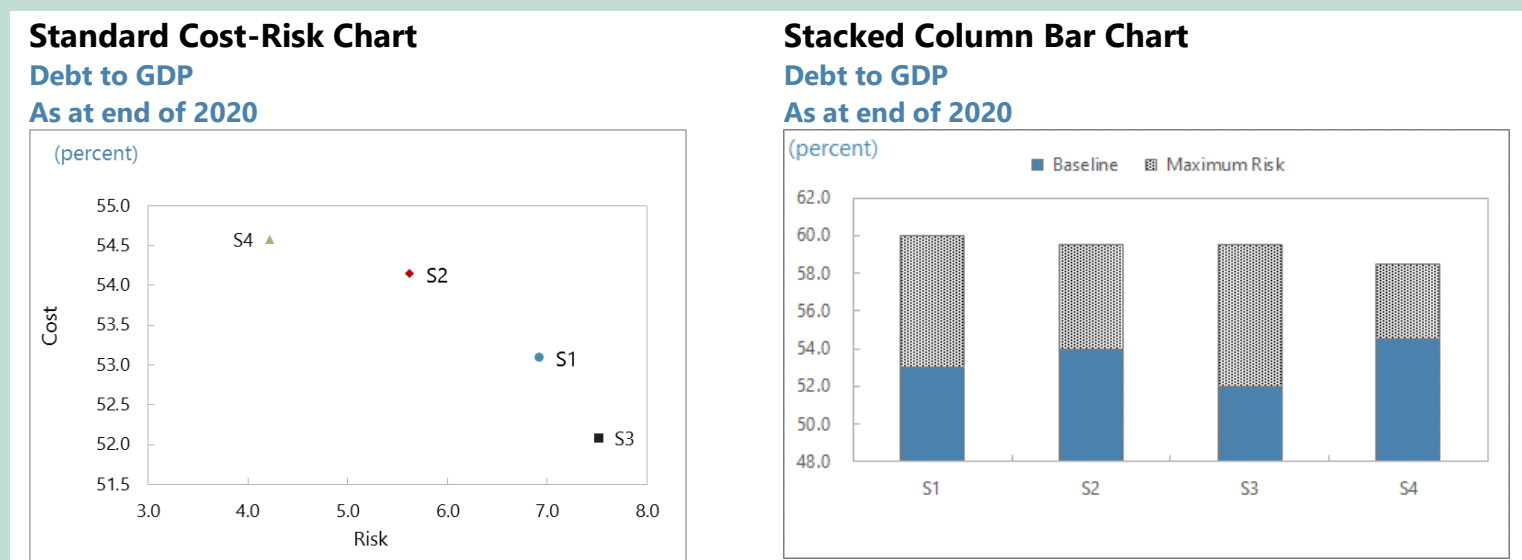

In addition to quantitative cost and risks, when selecting a strategy, users should also consider primary debt management objectives, such as developing the domestic market, which may mean choosing a strategy that is not optimal in terms of minimizing cost or risks.

\subsection{The "Strategy $1-4$ " Worksheets}

71. The Strategy $\mathbf{1}$, Strategy $\mathbf{2}$, Strategy 3 , and Strategy $\mathbf{4}$ worksheets save results of Total Debt worksheet for a given borrowing strategy and the five scenarios for exchange rates and interest rates, in local currency. The structure of these sheets is identical, with sets of 400 rows used to report result for the five scenarios.

\subsection{The "New Debt (Original Currency)" Worksheet}

72. No data entry is required in the New Debt (Original Currency) worksheet. The MTDS AT automatically simulates cash flows generated by the new debt issued to cover the gross 
financing needs over the projection period, disaggregated into the 20 stylized debt instruments, given a certain borrowing strategy and the projected values for exchange rates and interest rates.

73. For instance, for the debt Instrument 1-the ADF-like loan-disbursed in the first year of the projection period, the MTDS AT calculates and reports the initial cash inflow (at issuance date) and all the subsequent cash outflows (at principal and interest payment dates) associated with that instrument, in its original currency. The MTDS AT also reports the debt outstanding and present value of debt, which are stock measures. Hence, the entire 'history' of this instrument can be tracked.

74. It should be noted that the cash flows described above will depend on: (i) the financing terms of Instrument 1; (ii) the amount of Instrument 1 in original currency disbursed in the first year of the projection period; and (iii) the projected for interest rates.

75. The user will note that for all stylized debt instruments and years, the structure of rows is the same, covering new disbursement, principal repayment, total debt outstanding, interest payments, debt service, and present value of debt. The user can look at the Excel formulas to observe and trace how cash flow projections are generated using the information provided in the AT.

\subsection{The "New Debt (Domestic Currency)" Worksheet}

76. No data entry required in the New Debt (Domestic Currency) worksheet. Here, the MTDS AT converts the cash flows generated in the New Debt (Original Currency) worksheet into domestic currency. The user can note that for all stylized debt instruments and years, the structure of rows is the same as in the New Debt (Original Currency) worksheet, covering new disbursement, principal repayment, total debt outstanding, interest payments, debt service, and present value of debt.

77. At the top of the worksheet there is a section that aggregates cash flows of all debt instruments, taking advantage of the fact that all cash flows are in local currency and therefore can be added up.

\subsection{The "Total Debt" Worksheet}

78. No data entry required in the Total Debt worksheet. Here, the MTDS AT simply consolidates the cash flows generated by the existing debt (calculated in the Existing Debt sheet) and new debt issued to cover the gross financing needs over the projection period (calculated in sheet New Debt (Domestic Currency)), disaggregated into the 20 stylized debt instruments. 


\section{ANNEX A \\ Quarterly Cash Flow Analytical Tool}

The MTDS AT is based on annual cash flow. While this assumption is sufficient for analyzing alternative debt management strategies, in some cases, particularly for countries that are heavily dependent on short-term securities with maturities of less than a year, it would be helpful to work with cash flows with higher frequency. Such toolkit is helpful in capturing interest payments that fall within a year, such as interest payments on Treasury bills (T-bills), and for developing an annual borrowing plan. ${ }^{30}$

The quarterly cash flow analytical tool (QAT) works in the same way as the MTDS AT based on quarterly cash flow. The main difference between QAT and AT, is that the input data required is quarterly rather than annual. The differences in the three input sheets are described in the Table A.1 below. The Output worksheets are similar to the MTDS AT, but the cash flow calculations in the New Debt (Original Currency), New Debt (Domestic Currency), and Total Debt worksheets are all based on quarterly cash flows.

Furthermore, there are four new worksheets that can be helpful, in designing annual borrowing plan, Strategy 1QCF Strategy 2QCF Strategy 3QCF and Strategy 4QCF. As the name implies, these worksheets display the quarterly equivalent cash flow of the Strategy 1, Strategy 2,

Strategy 3, and Strategy 4 ( $\$ 19$, and $\Uparrow 60)$.

${ }^{30}$ In the MTDS AT, the shortest instrument, is assumed to have one-year maturity. 


\begin{tabular}{|c|c|c|}
\hline \multicolumn{3}{|c|}{ Table A.1 Key Difference Between MTDS AT and QAT } \\
\hline Worksheet Name & Input Areas & Description of Changes \\
\hline \multirow{4}{*}{ Existing_Debt } & $\begin{array}{l}\text { Key Parameters \& } \\
\text { Instruments: Time Horizon }\end{array}$ & $\begin{array}{l}\text { Entries are still in years. Please note the maximum period for } \\
\text { strategy is } 5 \text { years. }\end{array}$ \\
\hline & $\begin{array}{l}\text { Key Parameters \& } \\
\text { Instruments: Stylized } \\
\text { Instruments (Maturity, } \\
\text { Grace and Coupon } \\
\text { Periods) }\end{array}$ & $\begin{array}{l}\text { Maturities and grace period years are entered in terms of } \\
\text { quarters, and the user will also note new column to specify } \\
\text { coupon payment period, column I. } \\
\text { For example, if an instrument has a } 10 \text {-year maturity and grace } \\
\text { period of } 3 \text { years, then the entry in column } \mathrm{G} \text { should be } 40 \text {, and } \\
\text { the entry in column } \mathrm{H} \text { should be } 12 \text {. For interest/coupon } \\
\text { payments that are based on annual basis, entry in column I } \\
\text { should be } 4 \text {, for semi-annual payments, it should be } 2 \text { and for } \\
\text { quarterly payments, it is } 1 \text {. }\end{array}$ \\
\hline & $\begin{array}{l}\text { Existing Debt Cash Flow } \\
\text { from Database: Principal } \\
\text { repayments }\end{array}$ & $\begin{array}{l}\text { Principal repayments are entered in the quarter they are } \\
\text { projected to be paid. }\end{array}$ \\
\hline & $\begin{array}{l}\text { Existing Debt Cash Flow } \\
\text { from Database: Interest } \\
\text { payments }\end{array}$ & $\begin{array}{l}\text { Interest payments are entered in the quarter they are expected } \\
\text { to be paid. }\end{array}$ \\
\hline \multirow{4}{*}{$\begin{array}{l}\text { Macro and Market } \\
\text { Data }\end{array}$} & Macro Information & $\begin{array}{l}\text { Data should be entered on quarterly basis apart from GDP. } \\
\text { If breakdown of macro projections on a quarterly basis is not } \\
\text { available, the user can use the annual projections by } \\
\text { distributing them across } 4 \text { quarters. }\end{array}$ \\
\hline & Exchange Rate projections & $\begin{array}{l}\text { Quarterly depreciations should be entered in the exchange rate } \\
\text { area: F81: Y86. Hence, if } 2 \text { percent is entered for four quarters } \\
\text { consecutively, the annual depreciation will be } 8.24 \text { percent. }\end{array}$ \\
\hline & Interest Rate projections & $\begin{array}{l}\text { Annual interest rates are entered for all periods. The cash flow } \\
\text { calculations will take into account the frequency of } \\
\text { coupon/interest payments based on entries in the Existing_Debt } \\
\text { worksheet for each stylized instrument. }\end{array}$ \\
\hline & $\begin{array}{l}\text { Operational and cash } \\
\text { buffer targets }\end{array}$ & $\begin{array}{l}\text { Quarterly targets are required. Please note that this would mean } \\
\text { that cash buffers built in the first half of the year can be used } \\
\text { towards the end of the same year (an option not available in the } \\
\text { annual cash flow based AT). } \\
\text { The operational target for net domestic financing as a } \\
\text { percentage of GDP is not available. }\end{array}$ \\
\hline Strategy & $\begin{array}{l}\text { Strategy percentages by } \\
\text { instrument }\end{array}$ & $\begin{array}{l}\text { Quarterly inputs are required with the sum for external and } \\
\text { domestic each totaling } 100 \text { percent. The allocation by } \\
\text { instruments should help in designing an annual borrowing plan. }\end{array}$ \\
\hline
\end{tabular}




\section{ANNEX B \\ A Summary of Main Changes}

\section{Changes to the Analytical Tool}

\section{MTDS AT 2015 Version $^{31}$}

Instructions

Representative

Instruments

Outputs

New features

(All are optional)
Key instructions summarized in a single worksheet

Must be entered in the choice of one main foreign currency, often USD or EUR

Maximum of 15

Interest type: Variable or Fixed

Outputs: charts and table

Risk Indicators: Tables by strategy and then by Indicators (baseline)

Redemption profile

\section{Current Version}

Divided into three worksheets

- READ ME

- Instructions worksheet with all input cells identified

- List of Outputs (hidden by default)

Option to enter either in local currency or in the choice of one main foreign currency, e.g., USD

Maximum of 20

Interest type: Variable, Fixed or T-bills (to easily distinguish T-bills)

Outputs divided into:

- tables of outputs

- charts

- pricing charts

Redemption profile divided by:

- currency mix: FX-DX

- interest mix

Non-budgetary sources of financing (Annex C)

Non-budgetary expenses (Annex D)

Cash buffers (Manual section 4.4.3)

Indexed Instruments (Manual section 4.2.1 and Box 3)

\footnotetext{
31 The most recent version publicly available on the WB website.
} 


\section{May 2012 version $^{32}$}

Style

Introduction

General Structure of MTDS AT

Process Overview

Getting Started

Appendix
Mainly gave instructions on how to populate the tool, while giving brief descriptions of each worksheet and key inputs needed. ${ }^{33}$

Summarizes each types of worksheets by their role: input, calculation, output.

Describes how cash flow are generated for each strategy under the five scenarios including the baseline.

Instructs how to populate each input worksheet, while describing other areas where calculations are generated.

It also describes the worksheets where the cash flows are derived.

\section{Current Version}

In addition to describing each worksheet and data input required, descriptions of each input and worksheet, the structure of the tool and links between each sheet are more detailed.

Includes text on the MTDS framework.

Renamed "Overview of the Analytical Tool" it provides a synopsis of the tool, describing very briefly the inputs, the analysis and the outputs. Useful for readers that want a summary of what MTDS AT does.

Renamed "Components of the Tool" is a preamble to the detailed instructions section that follows. For example, it describes the types of scenarios that will be considered; this section informs the user on what to expect as inputs and it can also be used as a quick reference for locating information within the tool.

Renamed "The Analytical Tool: Modus Operandi", provides detailed (a) instruction on inputting data, and (b) information of special cases and particularities.
Excluding the annex on the Quarterly Cash flow (not applicable for the previous how to derive borrowing strategies under quantitative restrictions.

\footnotetext{
32 The previous version is from May 2012, "Medium-Term Debt Management Strategy: The Analytical Tool, User Guide, May 2012".

33 Taking exchange rate as an example, the previous version informs the user how the exchange rate information required for the tool are used in each worksheet and gives instructions where to input the exchange rate data. The current version contains the same information and in addition informs the user that exchange rate shock scenario is sustained into the future as a one-off but permanent appreciation/depreciation that is not reversed.
} 


\section{May 2012 version $^{32}$}

\section{Current Version}

version) and this annex, there are 12 annexes, that provide:

(a) Guidance on how to incorporate:

- non-budget borrowing sources

- non-budget expenses

- strategies with known loan disbursements

- strategies with quantitative restrictions

- incorporating Liability Management Operations

- strategies with a single instrument as a residual financing

(b) Guidance on how to:

- derive the annual interest payments and rate for outstanding T-bills on existing debt

- analyze SDR denominated debt (in terms of exchange rate risk)

- derive exchange rate depreciation based on purchase power parity theory

- derive a domestic yield curve or USD yield curve for non-regular issuers of USD international bond (Eurobond)

- derive forward yield curves

(c) A list of:

- all formulae used in the AT

- all Excel Macros and functions used in the AT 


\section{ANNEX C \\ Non-Budgetary Funding Sources ${ }^{34}$}

The AT allows the user to include non-budgetary sources of funding which can be used to reduce the gross borrowing requirement. The sources will differ from country to country, in the AT, deposits, asset sale proceeds are indicated as possible sources.

Please note that as noted in Box 8, cell E36in the Macro and Market Data worksheet is dedicated to the Existing Cash Buffers; the entry there is linked with cash buffer targets in the strategy period.

Other non-budgetary gross borrowing reduction items, such as funds available (other than cash buffers), proceeds from asset sale, should also be included. This annex illustrates how these nonbudgetary sources can be used.

Consider the following scenario:

- The strategy period is four years, the country is Utopia, the local currency is UTP, and debt data units are in millions, and

- Utopia has deposits, of UTP 5,000 million (not included in the existing cash buffer) where only a portion of this is available per annum to reduce gross borrowing; assume UTP 1,250 million per annum.

The user should enter the following in the Macro and Market Data worksheet to utilize the UTP 1,250 million of desposits per year:

- in cells F19:I19, enter the number 25, which translates into 25 percent, and

- in Row 15, enter 5000 for the strategy period from columns $\mathrm{F}$ to I.

This will allocate UTP 1,250 million per annumn for the four stratey period years.

Similarly, if there are other sources of financing that can be used to reduce gross financing, they should be entered in this area.

\footnotetext{
34 The example in this annex, and subsequent ones, is purely illustrative. The purpose is to show at least one mechanism on how the analytical tool can be used for special cases. We caution the user from drawing strategy or policy recommendations.
} 


\section{Annex D \\ Non-Budgetary Expenses ${ }^{35}$}

The AT can accommodate the inclusion of non-budgetary expenses, such as contingent liabilities, arrears, repayment of overdrafts, etc. This annex uses contingent liabilities to illustrate how the area in Macro and Market Data worksheet can be used to incorporate contingent liabilities into strategy analysis. Contingent liabilities can take different forms (for example, explicit or implicit government guarantees). If they materialize they can become part of the government debt portfolio. While the MTDS analytical tool is not suited for detailed analysis of contingent liabilities, the user of the model may find it useful to assess their impacts on the debt portfolio cost-risk matrix. ${ }^{36}$

Consider a scenario where the user has obtained contingent liability information (in cash flow terms) on state-owned enteprises as follows:

\begin{tabular}{lll} 
in millions of UTP & 2018 & 2019 \\
\hline Total & 3,000 & 1,500
\end{tabular}

However, the expected loss, or the financing requirement, that could emerge in any given year is less certain. To err on the side of caution, if the user wishes to examine strategies with different probabilities of default, the user should enter the above values in Row 27, that is, the entire cashflow of the contingent liability, and use Row 31 to capture the different probabilities of default (Figure D.1). Each strategy must be run separately, by changing the input in Row 31 before doing so.

Figure D.1 Using Strategies to Differentiate Loss from Contingent Liabilities

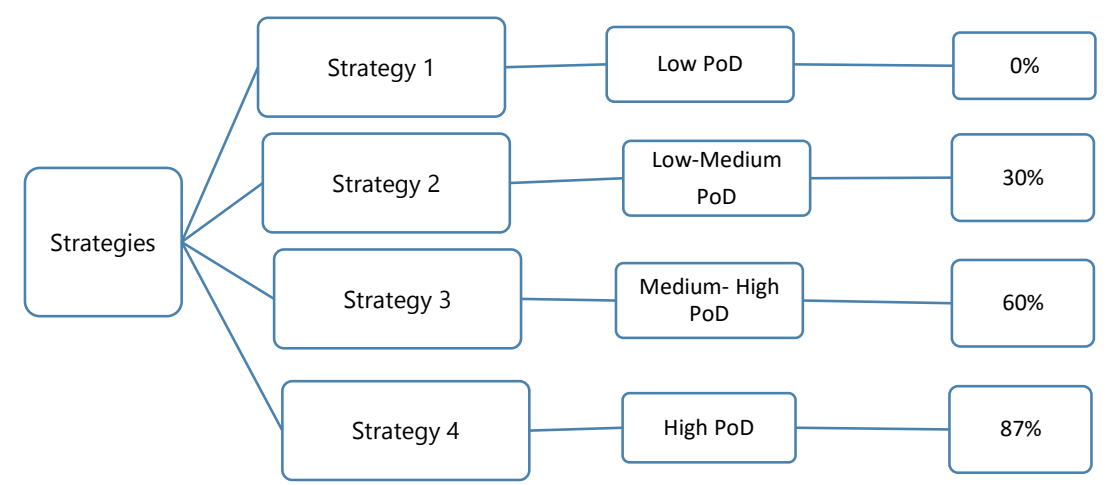

\footnotetext{
35 The example in this annex is purely illustrative. The purpose is to show at least one mechanism on how the analytical tool can be used for special cases. We caution the user from drawing strategy or policy recommendations.

${ }^{36}$ It should be noted that analyzing risks related to contingent liabilities often goes beyond the scope of the explicit responsibilities of the debt manager. Instead, tools developed by the IMF and WB's such as public-private partnership (PPP) Fiscal Risk Assessment Model can assist countries in assessing potential fiscal costs and risks arising from PPPs, while the Debt, Investment and Growth model, is helping countries to analyze the debt sustainability of large scale public investment programs.
} 


\section{Annex E \\ Strategies with Known Loan Disbursements ${ }^{37}$}

Several countries know with some certainty the schedule and amount of loan disbursements from some creditors, particularly multilaterals. ${ }^{38}$ In such cases, the user of the model should convert the absolute amounts into strategy percentages, that can then be entered into the relevant areas of the Strategy worksheet (Strategy 1, Q56: Z75, Strategy 2, AD56:AM75, Strategy 3, AQ56:AZ75, and Strategy 4, BD56: BM75).

Consider the following scenario:

- The strategy period is four years, the country is Utopia, the local currency is UTP, the base currency is USD, and macroeconomic and debt data units are in millions. Since the base currency is USD, existing debt data are entered in USD (please see the manual for debt data preparation for more information).

- The user wishes to formulate at least one strategy reflecting pre-determined disbursements from multilateral creditors in millions of USD which are as follows:

In millions of USD

\begin{tabular}{llrrrr} 
& Stylized Instruments & $\mathbf{2 0 1 8}$ & $\mathbf{2 0 1 9}$ & $\mathbf{2 0 2 0}$ & $\mathbf{2 0 2 1}$ \\
\hline USD_1 & ADF_Fixed & 137 & 96 & 102 & 85 \\
USD_2 & IDA/IFAD/EDF_Fixed & 93 & 61 & 78 & 53 \\
USD_3 & IBRD/ADB/IDB_Fixed & 75 & 49 & 57 & 42
\end{tabular}

- Furthermore, the user is able to project other sources of external (foreign currency) borrowing; these could be nil in some cases (if none is expected). For the purpose of this scenario, it is assumed that the user expects borrowing from bilateral creditors and international bond issuance as follows:

In millions of USD

\begin{tabular}{llrrrr} 
& Stylized Instruments & $\mathbf{2 0 1 8}$ & $\mathbf{2 0 1 9}$ & $\mathbf{2 0 2 0}$ & $\mathbf{2 0 2 1}$ \\
\hline USD_5 & Bilateral_Fixed & 34 & 44 & 18 & 22 \\
USD_7 & International Bond_Fixed & & & & 500
\end{tabular}

The user can use the optional area in the Macro and Market Data worksheet, or the area beneath the strategy input area in the Strategy sheet from row 200 onwards, for example Q200:

\footnotetext{
37 The illustration in this annex, and subsequent ones, is designed to purely show the mechanics of how the analytical tool can be used for special cases. We caution the user from drawing recommendations of strategy or policy formulations.

38 In some cases, loans contracted to be disbursed in future years are linked (with strict conditions) to particular projects, in such cases, users would need to make sure that the expenditure associated with such projects are reflected as part of primary expenditure (above the line) if the loan disbursements are considered as part of financing strategy.
} 
Z220 under Strategy 1 to enter the above values for instruments USD_1, USD_2, USD_3, USD_5, and USD_7.

The user then has several options on how to integrate the above as part of a strategy. The most straightforward option would be to select the operational target that sets Gross External Financing in millions of USD, and enter the sums of the above instruments for each year, and then their respective percentages are entered in the Strategy worksheet.

Assuming this scenario is part of Strategy 1: the user should then enter the following, in the Strategy worksheet:

\begin{tabular}{|c|c|c|c|c|c|}
\hline \multicolumn{6}{|c|}{ In millions of USD } \\
\hline \multicolumn{2}{|c|}{ Operational Target } & 2018 & 2019 & 2020 & 2021 \\
\hline \multicolumn{2}{|c|}{ Cell references } & Q29 & R29 & S29 & $\mathrm{T} 29$ \\
\hline \multicolumn{2}{|c|}{ GEF (millions of USD) } & 339 & 250 & 255 & 202 \\
\hline \multicolumn{6}{|c|}{ In percent } \\
\hline \multicolumn{2}{|c|}{ Strategy Percentages /1 } & 2018 & 2019 & 2020 & 2021 \\
\hline & Cell references & & & & \\
\hline USD_1 & Q56: Z56 & 40.41 & 38.40 & 40.00 & 12.11 \\
\hline USD_2 & Q57: Z57 & 27.43 & 24.40 & 30.59 & 7.55 \\
\hline USD_3 & Q58: Z58 & 22.12 & 19.60 & 22.35 & 5.98 \\
\hline USD_4 & Q59: Z59 & 0 & 0 & 0 & 0 \\
\hline USD_5 & Q60: Z60 & 10.03 & 17.60 & 7.06 & 3.13 \\
\hline USD_6 & Q61: Z61 & 0 & 0 & 0 & 0 \\
\hline USD_7 & Q62: Z62 & 0 & 0 & 0 & 71.23 \\
\hline USD_8 & Q63: Z63 & 0 & 0 & 0 & 0 \\
\hline USD_9 & Q64: Z64 & 0 & 0 & 0 & 0 \\
\hline USD_10 & Q65: Z65 & 0 & 0 & 0 & 0 \\
\hline
\end{tabular}

1 / In this illustration, the sum for each year may not add up to 100 because of rounding.

Please note that:

- if the strategy period was longer than four years and specific information on disbursement was not available, the user can enter best estimates of disbursements for each of the above stylized instruments for subsequent years based on information available at the time of designing and assessing alternative strategies, and

- before running the strategy, percentages for domestic instruments UTP_11 to UTP_20 will also need to be populated with their sum should equaling to 100 percent ( $\$ 60$. 


\section{Annex F \\ Strategies with Quantitative Restrictions ${ }^{39}$}

Gross financing needs depend on the primary deficit and the debt service corresponding to the existing and new debt portfolio. It is therefore not possible to enter the absolute amounts to be issued by instrument in the second year (or any subsequent year) of the projection period, because the gross financing amounts are not known in advance.

Defining borrowing requirements by instrument in absolute value terms is possible however, by running the model iteratively. ${ }^{40}$ This can be achieved by observing the gross financing need in the first year and then dividing this amount across instruments using absolute values. These absolute values can then be converted into percentages and entered into the relevant strategy cells. The AT can then be run with these values in the relevant strategy cells, and based on the result for year 1, similar calculations can be performed to compute the gross financing needs for the second year. Cash flows associated with new borrowing during the first year will be reflected in the computed financing need for year 2. It is then possible to enter absolute values by instrument to meet the gross financing needs in the second year and run the model again. This process can be repeated until absolute values have been entered for all years.

To illustrate, we continue with the scenario set out in Annex $E$, where the user has chosen the operational target that sets gross external financing and derived the percentages of external borrowing. In order to run the strategy in Annex E, the user had made the following working assumptions for domestic securities before running the analytical tool.

\begin{tabular}{llrrrr} 
In percent & & & & \\
& Stylized Instruments & $\mathbf{2 0 1 8}$ & $\mathbf{2 0 1 9}$ & $\mathbf{2 0 2 0}$ & $\mathbf{2 0 2 1}$ \\
\hline UTP_11 & T-bills & 50.00 & 50.00 & 50.00 & 50.00 \\
UTP_12 & T-Bonds 3 YR_Fixed & 20.00 & 20.00 & 20.00 & 20.00 \\
UTP_13 & T-Bonds 5 YR_Fixed & 20.00 & 20.00 & 20.00 & 20.00 \\
UTP_14 & T-Bonds 10 YR_Fixed & 10.00 & 10.00 & 10.00 & 10.00 \\
In millions of UTP & & & & \\
$\quad$ Stylized Instruments & $\mathbf{2 0 1 8}$ & $\mathbf{2 0 1 9}$ & $\mathbf{2 0 2 0}$ & $\mathbf{2 0 2 1}$ \\
\hline UTP_11 & T-bills & 4,292 & 4,108 & 4,622 & 6,474 \\
UTP_12 & T-Bonds 3 YR_Fixed & 1,717 & 1,643 & 1,849 & 2,590 \\
UTP_13 & T-Bonds 5 YR_Fixed & 1,717 & 1,643 & 1,849 & 2,590 \\
UTP_14 & T-Bonds 10 YR_Fixed & 858 & 822 & 924 & 1,295 \\
& & & & & \\
& Gross Domestic Financing & 8,584 & 8,215 & 9,245 & 12,948
\end{tabular}

\footnotetext{
${ }^{39}$ The illustration in this annex, and others, is designed to purely show the mechanics of how the analytical tool can be used for special cases. We caution the user from drawing recommendations of strategy or policy formulations.

40 Instead of running the strategy year by year, the process can be done in one step as illustrated in Annex G; running the strategy iteratively helps the user to see by how much gross domestic financing is changing year by year which may influence the size of issuance by each instrument.
} 
Now, consider domestic market capacity restrictions, where Utopia has limited capacity in issuing long-dated domestic instruments. The domestic market appetite for domestic government securities for bonds (securities of longer than one-year maturity) is as follows:

In millions of UTP

\begin{tabular}{llrrrr} 
& Stylized Instruments & $\mathbf{2 0 1 8}$ & $\mathbf{2 0 1 9}$ & $\mathbf{2 0 2 0}$ & $\mathbf{2 0 2 1}$ \\
\hline UTP_12 & T-Bonds 3 YR_Fixed & 3,000 & 3,000 & 3,000 & 3,000 \\
UTP_13 & T-Bonds 5 YR_Fixed & 1,500 & 1,500 & 1,500 & 1,500 \\
UTP_14 & T-Bonds 10 YR_Fixed & 750 & 750 & 750 & 750
\end{tabular}

Starting with the first year of analysis, 2018, and examining the components of gross financing requirement:

- Primary deficit is exogenous to the analytical tool, and calculated in the Macro and Market Data worksheet, Row 56 by taking the difference between expenditure and revenue. ${ }^{41}$ In our illustration, let us assume, primary deficit is UTP 5,746 million, cell F56.

- Interest payment is determined by entries in Existing Debt worksheet. Indeed, interest payments for the first year is determined outside the analytical tool apart from those instruments with floating (variable) rates. In our example, assume, interest payment for year 2018, is UTP 1,819 million (in Existing Debt worksheet in cell F357 Strategy 1 cell F155, or in Macro and Market Data worksheet in cell F57).

- Amortization, similar to interest payment, is also determined by entries in Existing Debt worksheet. In our example, assume, amortization for year 2018, is UTP 6,359 million (in Existing Debt worksheet in cell F310, Strategy 1 cell F71, or in Macro and Market Data worksheet in cell F60). ${ }^{42}$

- Gross financing: based on the sum of the three above gross financing for year 2018 is UTP 13,924 million.

Since the operational target sets external financing at US\$339 million (equivalent to UTP 5,339 million), gross domestic financing is the residual, UTP 8,584 million (cell Q43 in the Strategy worksheet). The percentage for each bond can then calculated, giving a sum of 61.16 , meaning the remaining 38.84 will be allocated to T-bills. Once the percentages have been entered (see the table below) in Q66:Q69, the strategy will have to be run so that the gross financing figures for year 2019 is calculated with the new percentages for year 2018 (the user can use the Excel Macros for individual strategies found in the READ ME worksheet). Based on the new gross domestic financing figure, which is UTP 7,273 million, the percentages for 2019 can be calculated with the above restrictions. The new percentages are indicated in the table below. Running the strategy with the new percentages for 2018 and 2019 (and external financing assumptions as in

\footnotetext{
${ }^{41}$ In the MTDS AT, primary deficit (surplus) is positive (negative).

42 Note, that the AT would have to run for Strategy 1 to be populated; in this case by using the assumptions in Annex E.
} 
Annex E), provide gross domestic financing of UTP 7,381 million for year 2020. Repeating the same process, new percentages are calculated for 2020, and then 2021.

\begin{tabular}{llrrrr} 
In percent & & & & \\
& Stylized Instruments & $\mathbf{2 0 1 8}$ & $\mathbf{2 0 1 9}$ & $\mathbf{2 0 2 0}$ & $\mathbf{2 0 2 1}$ \\
\hline UTP_11 & T-bills & 38.8 & 27.8 & 28.9 & 55.7 \\
UTP_12 & T-Bonds 3 YR_Fixed & 34.9 & 41.2 & 40.6 & 25.3 \\
UTP_13 & T-Bonds 5 YR_Fixed & 17.5 & 20.6 & 20.3 & 12.7 \\
UTP_14 & T-Bonds 10 YR_Fixed & 8.7 & 10.3 & 10.2 & 6.3 \\
& & & & & \\
& Gross Domestic Financing & 8,584 & 7,273 & 7,381 & 11,843
\end{tabular}




\section{Annex G \\ Using a Single Instrument for Residual Financing ${ }^{43}$}

As noted in Annex $\mathrm{F}$ gross financing needs depend on the primary deficit and the debt service corresponding to the existing and new debt portfolio. While it is not possible to enter the absolute amounts to be issued for each instrument in the second year (or any subsequent year) of the projection period, because the gross financing amounts are not known in advance, it is possible to use one instrument such as T-bills as a residual financing and plan the amount of borrowing for the remaining instruments. This approach can be particularly helpful to translate the selected strategy into an annual borrowing plan.

Annex $\mathrm{F}$ showed how borrowing requirements can be specifically set by each instrument in absolute value terms by running the model iteratively. This option is less restrictive in that the tool does not need to be run iteratively, as at it relies on the residual financing instrument to deal with uncertainty or variability in debt service payments from one year to the next in the strategy period.

To illustrate, we continue with a similar scenario set out in Annex E and F, where:

- the user has chosen the operational target that sets gross external financing (where financing by each creditor is also known), and

- domestic market capacity is shallow, limiting the amount that can be sourced through medium and long-term bonds

As follows:

(millions of USD)

\begin{tabular}{llrrrr} 
& Stylized Instruments & $\mathbf{2 0 1 8}$ & $\mathbf{2 0 1 9}$ & $\mathbf{2 0 2 0}$ & $\mathbf{2 0 2 1}$ \\
\hline USD_1 & ADF_Fixed & 150 & 100 & & \\
USD_2 & IDA/IFAD/EDF_Fixed & 150 & 100 & 150 & 100 \\
USD_3 & IBRD/ADB/IDB_Fixed & 100 & 100 & & \\
USD_5 & Bilateral_Fixed & 100 & 100 & 50 & \\
& & & & & \\
(millions & of UTP) & & & & \\
$\quad$ Stylized Instruments & $\mathbf{2 0 1 8}$ & $\mathbf{2 0 1 9}$ & $\mathbf{2 0 2 0}$ & $\mathbf{2 0 2 1}$ \\
\hline UTP_12 & T-Bonds 3 YR_Fixed & 3,000 & 3,000 & 3,000 & 3,000 \\
UTP_13 & T-Bonds 5 YR_Fixed & 1,500 & 1,500 & 1,500 & 1,500 \\
UTP_14 & T-Bonds 10 YR_Fixed & 750 & 750 & 750 & 750
\end{tabular}

${ }^{43}$ The illustration in this Annex, and others, is designed to purely show the mechanics of how the analytical tool can be used for special cases. We caution the user from drawing recommendations of strategy or policy formulations. 
To use T-bills as the residual financing and ensure financing by the above instruments are restricted as set out in the table, the following approach can be applied:

- First, set the operational target in terms of gross external financing, which can be derived by summing the amounts raised through instruments USD_1, USD_2, USD_3, and USD_5.

\begin{tabular}{lrrrr} 
(millions of USD) & $\mathbf{2 0 1 8}$ & $\mathbf{2 0 1 9}$ & $\mathbf{2 0 2 0}$ & $\mathbf{2 0 2 1}$ \\
\hline GEF & 500 & 400 & 200 & 100
\end{tabular}

- Second, in a working area, (for example, the area Q190 and below in the Strategy worksheet) convert the amount into UTP using the applicable exchange rate per year from the Macro and Market Data worksheet.

\begin{tabular}{lllll} 
(millions of UTP) & $\mathbf{2 0 1 8}$ & $\mathbf{2 0 1 9}$ & $\mathbf{2 0 2 0}$ & $\mathbf{2 0 2 1}$ \\
\hline Financing from external & 7,875 & 6,489 & 3,374 & 1,687
\end{tabular}

- Third, determine how much needs to be raised through T-bills by setting up a formula that takes the difference between gross financing requirement in UTP and external financing plus financing from UTP_12, UTP_13, and UTP_14 (which happens to be UTP 5,250 million every year in the strategy period).

\begin{tabular}{lrrrr} 
(millions of UTP) & $\mathbf{2 0 1 8}$ & $\mathbf{2 0 1 9}$ & $\mathbf{2 0 2 0}$ & $\mathbf{2 0 2 1}$ \\
\hline Financing from T-bills & 799 & $(2,996)$ & $(2,073)$ & 4,036
\end{tabular}

- Lastly, determine the percentages for each representative instrument to enter into area Q56: T75 in the Strategy worksheet.

- For USD_1, USD_2, USD_3, and USD_5; this would simply be dividing the amounts by the operational target.

$\begin{array}{lrrrr}\text { (in percent) } & \mathbf{2 0 1 8} & \mathbf{2 0 1 9} & \mathbf{2 0 2 0} & \mathbf{2 0 2 1} \\ \text { USD_1 } & 30 & 25 & & \\ \text { USD_2 } & 30 & 25 & 75 & 100 \\ \text { USD_3 } & 20 & 25 & & \\ \text { USD_5 } & 20 & 25 & 25 & \end{array}$

- For UTP_12, UTP_13, UTP_14; to determine the percentage, one needs to derive the aggregate domestic financing needed, as the difference between gross financing and external gross financing.

$\begin{array}{lrrrr} & \mathbf{2 0 1 8} & \mathbf{2 0 1 9} & \mathbf{2 0 2 0} & \mathbf{2 0 2 1} \\ \text { (millions of UTP) } & & & & \\ \text { Gross Financing Need } & 13,924 & 8,743 & 6,551 & 10,973 \\ \text { Gross External Financing } & 7,875 & 6,489 & 3,374 & 1,687 \\ \text { Gross Domestic Financing } & 6,049 & 2,254 & 3,177 & 9,286\end{array}$




$\begin{array}{lrrrr} & \mathbf{2 0 1 8} & \mathbf{2 0 1 9} & \mathbf{2 0 2 0} & \mathbf{2 0 2 1} \\ \text { (in percent) } & & & & \\ \text { UTP_12 } & 49.6 & 133.1 & 94.4 & 32.3 \\ \text { UTP_13 } & 24.8 & 66.6 & 47.2 & 16.2 \\ \text { UTP_14 } & 12.4 & 33.3 & 23.6 & 8.1\end{array}$

- For T-bills, UTP_11, the percentage should be calculated as a residual by taking the difference between 100 percent and the sum of percentages of instruments UTP_12, UTP_13 and UTP_14, to avoid circular references.

$\begin{array}{lrrrr} & \mathbf{2 0 1 8} & \mathbf{2 0 1 9} & \mathbf{2 0 2 0} & \mathbf{2 0 2 1} \\ \text { (in percent) } & 13.2 & (133.0) & (65.3) & 43.5 \\ \text { UTP_11 } & 13.2\end{array}$




\section{Annex H Incorporating Liability Management Operations ${ }^{44}$}

Straightforward liability management operations (LMOs), such as buyback and exchange of existing debt can be incorporated as part of a strategy in the AT. ${ }^{45}$ The user can set up two identical strategies except that one includes LMOs. The cost-risk results of the two strategies should help to inform the decision making on whether to proceed with LMOs. In this annex, we illustrate buyback and exchange operations, but before we proceed please note the following:

- While the AT can be used to analyze LMOs that involves the buyback or exchange of existing debt, its structure does not allow the analysis of similar operations for new debt,

- Since the operations entail changing the composition of existing debt portfolio, with those instruments involved in the LMOs being removed from the existing debt portfolio (either through buyback or replaced by new debt instrument), the user is advised to assign unique stylized instruments for such debt instruments. If the user has not allocated unique representative instruments during the data aggregation stage, it is possible to amend the existing debt data entries within the AT (as illustrated in this annex), and

- It is assumed that the user is able or has the capacity to determine the market price of instruments that are being bought back or exchanged (that is, the financing requirement for the LMOs are determined outside the AT).

Buybacks and exchanges can be thought of as two operations. Even though exchanges are undertaken as a single transaction, in analyzing the underlying operations, they can be thought of as two back-to-back simultaneous transactions. The first operation adjusts the composition of existing debt portfolio, by changing the cash flow entry for the instruments that are being bought back or exchanged, while the second operation ensures adequacy of funding for the operations through (a) increasing the financing requirement (or drawing down on cash buffer if available) in the case of buyback and (b) allocating the increase in financing to the chosen instruments (destination instruments), in the case of an exchange.

The illustration below considers the two types of LMOs, where each is illustrated in turn.

\footnotetext{
44 The illustration in this annex, and others, is designed to purely show the mechanics of how the analytical tool can be used for special cases. We caution the user from drawing recommendations of strategy or policy formulations.

45 The AT is less suitable to analyze liability management operations that are complex (for example, derivative transactions that include swaps, options, and swaptions).
} 
Consider the following starting assumptions:

- Assume for both LMOs, the strategy without the LMOs is the same as in Annex D and Annex $\mathrm{E}$

- Representative instrument UTP_12, in the existing debt data, represents two-year and three-year bonds. The aggregate outstanding size of the two-year as at end 2017, was US\$15.1 million (UST 255.7 million), and interest payments for year 2018 and 2019, were US\$2.1 million (UTP 31.53 million), and

- Out of the outstanding amount UTP 255 million, UTP 45 million is a single instrument with interest rate of 6 percent; we name this instrument, the bond that will be part of the LMOs, Bond A (source bond).

Option 1: Buybacks

- Suppose we wish to include a strategy that includes a buyback of Bond $A$, in the first year of analysis, year 2018, Strategy 3.

- The market value of Bond A is UTP (determined outside the MTDS AT) is UTP 51 million.

- Before analyzing Strategy 3, we need to make the following adjustments:

- change the cash flow (both principal and interest payments) of UTP_12 in the Existing Debt worksheet, and

- increase the gross financing requirement for year 2018 by UTP 51 million.

Amending the existing debt cash flow ${ }^{46}$

- Using the optional area in Macro and Market Data worksheet, we enter the cash flow information of Existing_Debt UTP_12 separating out Bond A as follows:

UTP_12 without Bond A

\begin{tabular}{llrrr} 
& \multicolumn{3}{c}{ Columns } & \\
Rows & D & F & G & H \\
39 & In millions of USD & 2018 & 2019 & 2020 \\
\cline { 2 - 5 } 40 & Principal & & 3.69 & 8.35
\end{tabular}

\footnotetext{
${ }^{46}$ Users can also create a separate sets of cash flow that reflect the intended changes that will come about from the planned LMOs. These cash flows can then be temporarily copied into the Existing Debt worksheet instead of going through the steps described in this section, "Amending the existing debt cash flow". Another approach would be to use negative financing for the source bond (Bond A) by assigning it a unique representative instrument, e.g., UTP_15, and ensuring that the negative financing mimics the interest payments and principal payment.
} 
$\begin{array}{llll}41 & \text { Interest } & 1.92 & 1.92\end{array}$

Bond A

\begin{tabular}{llrrr} 
& \multicolumn{3}{c}{ Columns } & \\
Rows & D & F & G & $H$ \\
42 & In millions of USD & 2018 & 2019 & 2020 \\
\cline { 2 - 4 } 43 & Principal & & 3.00 & \\
44 & Interest & 0.18 & 0.18 &
\end{tabular}

- Note: for both entries above, that is, UTP_12 without Bond A and Bond A, it is important not to link the data to Existing Data entries to avoid circularity later.

- In Macro and Market Data worksheet, enter the number "1" in cell E47 and multiply Bond A cash flows with cell E47, as follows:

\begin{tabular}{llrrr} 
& \multicolumn{4}{c}{ Columns } \\
Rows & D & $F$ & $G$ & $H$ \\
46 & In millions of USD & 2018 & 2019 & 2020 \\
\cline { 2 - 5 } 47 & Principal & & $=\$ E \$ 47^{*} G 43$ \\
48 & Interest & $=\$ E \$ 47^{*} F 44$ & $=\$ E \$ 47^{*} G 44$
\end{tabular}

- In Existing Debt worksheet, amend the principal and interest payments entries of UTP_12 so that they are the sum of in Marco and Market Data worksheet, "UTP_12 without Bond $\mathrm{A}^{\prime \prime}$ and the above area F47:G48.

- Thus, in the Existing Debt worksheet, cash flow for instrument UTP_12 look as follows:

\begin{tabular}{|c|c|c|c|c|}
\hline \multirow[b]{2}{*}{ Rows } & \multicolumn{4}{|c|}{ Columns } \\
\hline & & $\mathrm{F}$ & G & $\mathrm{H}$ \\
\hline & In millions of USD & 2018 & 2019 & 2020 \\
\hline \multirow[t]{8}{*}{66} & Principal & & $=$ 'Macro and Market & $=$ 'Macro and Market \\
\hline & & & Data'!G40+'Macro and & Data'!H40+'Macro and Market \\
\hline & & & Market Data'!G47 & Data'!H47 \\
\hline & Interest & $=' M a c r o$ and & $='$ Macro and Market & $='$ Macro and Market \\
\hline & & Market & Data'!G41+'Macro and & Data'!H41+'Macro and Market \\
\hline & & Data'!F41+'Macro & Market Data'!G48 & Data'!H48 \\
\hline & & and Market & & \\
\hline & & Data'!F48 & & \\
\hline
\end{tabular}

- Now, if E47 is zero then, the cash flow of UTP_12 in Existing Debt worksheet will exclude Bond $A$. 
Increasing the financing requirement

- In the optional area in Macro and Market Data worksheet, cell F50, we enter the market price of Bond A, in millions of UTP. This was determined outside the MTDS, which in our example, is UTP 51 million. Instead of entering 51 , we multiply 51 by Cell $E 50$ so that it is $=\$ E \$ 50 * 51$. In cell $E 50$, we enter the following formula, $=\operatorname{if}(E 47=1,0,1)$. This ensures that when the cash flow of UTP_12 in Existing Debt worksheet changes to exclude Bond $A$, that is bought back or exchanged, then the additional financing UTP 51 million is automatically picked up.

- We then need to ensure that the primary expenditure row in Macro and Market Data worksheet, row 5, incorporates cell F50. The user can use of the non-budgetary expenses rows, for example, cell F29 to pick up the amount of UTP 51, by entering in cell F29 the following formula, =F50, and enter 100 percent in cell F33.

- Finally, the user should first run all strategies with cell E47 =1, and then after changing cell E47 to zero, run Strategy 3, which includes LMO, individually, using the Excel Macros available in the READ ME or the Strategy worksheet.

Option 2: Exchanges

In addition to all the steps in Option 1, we need to ensure that the size of the bond that Bond A is being exchanged for, the destination bond, increases by at least UTP 51 million in year 2018. Assume that the five-year instrument, UTP_13, is the destination bond, then, in allocating the strategy percentages for Strategy 3, the amount raised by UTP_13 has to be sufficiently large to cover the cost of Bond A. In the Strategy worksheet, the percentage in cell AQ68, needs to be adjusted to ensure that UTP_13 raises at least UTP 51 million of gross financing (cell AQ96). 


\section{Annex I \\ T-bills: Interest Payments and Average Yields}

Except for the complementary quarterly cash flow tool that uses quarterly cash flow, Annex A and footnote 3, the Analytical Tool works on annual cash flow basis. As a result, T-bills are assumed to have a maturity of one year, the shortest maturity. As a financing instrument in the strategy horizon, T-bills, like other instruments, are assumed to be issued at par with interest accruing and paid the following year. This methodology should not usually materially influence the cost-risk outcomes of alternative strategies, and therefore the decision in selecting the appropriate strategy. However, for those countries that heavily rely on T-bills with maturities of less than six months, since the annual cash flow ignores the interest cost being accrued in-year, costs and risk may be underestimated, especially when interest rates are relatively volatile. For such countries, the quarterly cash flow tool might be utilized.

Users should also take note to correctly record the interest payment and interest rate associated with existing outstanding stock of T-bills. This annex illustrates how to calculate the interest payment from an outstanding stock of T-bills. It also provides guidance on calculating the annualized yield rate to record in the Macro and Market Data worksheet, which is different from the implied rate, calculated in the Existing Debt worksheet.

For each issuance, users should have information on the tenor, issuance yield rate, and the cash raised. However, at times, the only available information the user can easily access, is the discount rate and the face value. The illustrations below cover both scenarios. ${ }^{47}$

Scenario A: Outstanding stock is in cash raised, where yields are recorded; the shaded area shows information available to the user. The top row, calculations, shows how to derive interest payments.

\begin{tabular}{lcccccc} 
Calculations & \multicolumn{3}{c}{} & $=(\mathrm{C}) *[365 /(\mathrm{B})]$ & $=(\mathrm{A}) *[(1+\mathrm{C})]$ & $=(\mathrm{F})-(\mathrm{A})$ \\
& $(\mathrm{A})$ & $(\mathrm{B})$ & $(\mathrm{C})$ & $(\mathrm{D})$ & $(\mathrm{F})$ & $(\mathrm{G})$ \\
& Cash & Tenor & & Annualized & & Interest \\
Instruments & Raised & (Days) & Yields & Yield & Face Value & Payments \\
3 months & 1,533 & 91 & $3.00 \%$ & $12.03 \%$ & 1,578 & 46 \\
6 months & 1,341 & 182 & $7.05 \%$ & $14.14 \%$ & 1,435 & 95 \\
12 months & 958 & 365 & $15.35 \%$ & $15.35 \%$ & 1,105 & 147 \\
& 3,831 & & & & &
\end{tabular}

\footnotetext{
47 Debt analysts should move towards recording yields, which are more readily comparable to other instruments' cost of borrowing.
} 
Scenario $B$ : Outstanding stock is in cash raised, where discount rates are recorded; the shaded area shows information available to the user. The top row, calculations, shows how to derive interest payments.

$\begin{array}{lccccc}\text { Calculations } & & & & =(A) \div[(1-(E)] & =(F)-(A) \\ & (A) & (B) & (E) & (F) & (G) \\ & \text { Cash } & \text { Tenor } & \text { Discount } & & \text { Interest } \\ \text { Instruments } & \text { Raised } & \text { (Days) } & \text { Rates } & \text { Face Value } & \text { Payments } \\ 3 \text { months } & 1,533 & 91 & 2.91 \% & 1,578 & 46 \\ 6 \text { months } & 1,341 & 182 & 6.59 \% & 1,435 & 95 \\ 12 \text { months } & 958 & 365 & 13.31 \% & 1,105 & 147 \\ & 3,831 & & & & 288\end{array}$

Scenario C: Outstanding stock is in face value, where yields are recorded; the shaded area shows information available to the user. The top row, calculations, shows how to derive interest payments.

\begin{tabular}{|c|c|c|c|c|c|}
\hline \multirow[t]{2}{*}{ Calculations } & & & \multicolumn{2}{|l|}{$=(C) *[365 /(B)]$} & \multirow{3}{*}{$\begin{array}{c}=(F) *[(1-(1 \div(1+(C)))) \\
(G)\end{array}$} \\
\hline & (B) & (C) & (D) & (F) & \\
\hline Instruments & $\begin{array}{l}\text { Tenor } \\
\text { (Days) }\end{array}$ & Yields & $\begin{array}{c}\text { Annualized } \\
\text { Yield }\end{array}$ & Face Value & \\
\hline 3 months & 91 & $3.00 \%$ & $12.03 \%$ & 1,578 & 46 \\
\hline 6 months & 182 & $7.05 \%$ & $14.14 \%$ & 1,435 & 95 \\
\hline 12 months & 365 & $15.35 \%$ & $15.35 \%$ & 1,105 & 147 \\
\hline & & & & & 288 \\
\hline
\end{tabular}

Scenario D: Outstanding stock is in face value, where discount rates are recorded; the shaded area shows information available to the user. The top row, calculations, shows how to derive interest payments.

\begin{tabular}{|c|c|c|c|c|}
\hline \multirow[t]{3}{*}{ Calculations } & & & & \multirow{2}{*}{$\begin{array}{c}=(F) *(E) \\
(G)\end{array}$} \\
\hline & (B) & $(E)$ & (F) & \\
\hline & Tenor & Discount & & Interest \\
\hline Instruments & (Days) & Rates & Face Value & Payments \\
\hline 3 months & 91 & $2.91 \%$ & 1,578 & 46 \\
\hline 6 months & 182 & $6.59 \%$ & 1,435 & 95 \\
\hline 12 months & 365 & $13.31 \%$ & 1,105 & 147 \\
\hline & & & & 288 \\
\hline
\end{tabular}

The interest payments as derived above should be entered in the Existing Debt worksheet against the representative instrument for T-bills.

To compare the interest rate projections for T-bills in the strategy horizon against outstanding Tbills at the end of the base year (or start of the strategy period year), the weighted average annualized yield rate should be recorded in the Macro and Market Data worksheet. The 
weighted average annualized yield is calculated by using cash raised and annualized yield for each tenor (for example from Scenario $A$, multiplying columns (A) and (D) and dividing the result by the sum of column (A)). For cases similar to scenarios $C$ and $D$ where outstanding stock is in face value, users should calculate the cash raised by subtracting interest payments from face value, then working out the yields $=($ Face Value - Cash Raised $) \div$ Cash Raised

One should note that the weighted average annualized yield is different from the implied rate, calculated in the Existing Debt worksheet (areas: E101:E120; E219:E238; E313:E332). 


\section{Annex J \\ Debt Denominated in Special Drawing Rights}

Loans from the major multilateral institutions are often denominated in special drawing rights (SDRs). The value of the SDR is based on a basket of five major currencies, the U.S. dollar (USD), the euro (EUR), the Chinese renminbi (RMB), the Japanese yen (YEN), and the British pound sterling (GBP). The SDR currency value is calculated daily and information can be accessed on the IMF and World Bank websites. ${ }^{48}$

While countries can agree with creditors the currency for debt service payments, SDR loans give rise to exchange rate risk exposure originating from the five underlying currencies.

SDR denominated loans, existing and potential financing, should be treated as follows:

- For existing debt, users should look up the applicable exchange rate on the appropriate date to convert SDR loans into the major foreign currency used in the AT (for example, USD or euro), and convert further into local currency if existing debt data are entered in local currency, and

- For potential financing, use the major currency as opposed to SDR, for such instruments, while keeping in mind that the instruments pose exchange rate risk to five currencies.

In analyzing SDR denominated loans, the following illustration could be useful. Consider the following example:

As at the end of base year (end-Dec 2017), the aggregate size of SDR loans (the currency code for SDR is XDR) is: XDR 315 million.

The first step is to obtain the weighting (column B) and exchange rate (column C) information for $X D R$. Note that the weightings are reviewed every five years, so the next revision is not until September 2021.

\begin{tabular}{|c|c|c|c|}
\hline (A) & (B) & (C) & $(D)=1 \div(C)$ \\
\hline Currency & Weighting & Exchange Rate & FX Per 1 USD \\
\hline $\mathrm{CNY}^{/ 1}$ & $10.92 \%$ & 9.273 & 0.154 \\
\hline EUR & $30.93 \%$ & 1.187 & 1.199 \\
\hline GBP & $8.09 \%$ & 1.054 & 1.351 \\
\hline JPY & $8.33 \%$ & 160.785 & 0.009 \\
\hline USD & $41.73 \%$ & 1.424 & 1.000 \\
\hline
\end{tabular}

${ }^{1 / N}$ Note: the currency unit of renminbi is yuan with the code CNY

${ }^{48}$ Details on SDR are available on the IMF website. 
Then:

- to convert the XDR 315 million into USD, simply multiply by 1.424 or euro by 1.187 ;

- to understand the exchange rate risk exposure, first calculate the SDR amounts exposed to each currency. This implies multiplying XDR 315 million by the weighting of each currency, and then applying the corresponding exchange rates:

Exposure to the underlying five currencies in XDR

Currency

XDR millions

\begin{tabular}{lr}
\hline CNY & 34 \\
EUR & 97 \\
GBP & 25 \\
JPY & 26 \\
USD & 131 \\
\hline Total & 315
\end{tabular}

- the exposure in each currency can be calculated by applying the exchange rate in column $(C)$ above.

\begin{tabular}{lrr}
$\begin{array}{l}\text { Exposure to each currency } \\
\text { in its own denomination }\end{array}$ & millions & $\begin{array}{r}\text { Equivalent } \\
\text { in XDR } \\
\text { millions }\end{array}$ \\
\hline CNY & 319 & $=34$ XDR \\
EUR & 116 & $=97$ XDR \\
GBP & 27 & $=25$ XDR \\
JPY & 4,220 & $=26$ XDR \\
USD & 187 & $=131$ XDR
\end{tabular}

- If one multiplies the exchange rates in column (D), against the result above, the aggregate should equal to the XDR 315 million multiplied by 1.424 .

\begin{tabular}{lrr}
$\begin{array}{l}\text { Exposure to each currency } \\
\text { in its own denomination }\end{array}$ & 319 & $=49$ USD \\
\hline CNY & 116 & $\begin{array}{r}\text { Equivalent } \\
\text { in USD } \\
\text { millions }\end{array}$ \\
EUR & 27 & $=36$ USD \\
GBP & 4,220 & $=37$ USD \\
JPY & 187 & $=187$ USD \\
USD & & $=449$ USD \\
& & \\
XDR & 315 & $=449$ USD
\end{tabular}


This page intentionally left blank 


\section{Annex K \\ Projecting Exchange Rate}

Exchange rates are one of the market inputs required in the analytical tool. In many cases central banks or relevant line ministries (Finance or Economic Development) will have the required inputs. ${ }^{49}$ Market analysts and data providers are also other sources that may provide such information. In absence of such sources, users may apply purchasing power parity (PPP) principle to project the exchange rate. The path of exchange rate determined through PPP offsets differential inflation rates between countries to maintain a constant real exchange rate. Put another way, it determines by how much nominal exchange rate would need to adjust (depreciate or appreciate) to keep the real exchange rate constant over a given period.

Suppose:

Пuтp = Utopia inflation (domestic country)

Пus = U.S. inflation (foreign country)

Then PPP implies given a nominal exchange rate today, $S_{00}$, to keep the real exchange rate constant, the nominal exchange rate will have to adjust by the ratio of Пuтp to Пus in the next period.

Thus:

$\mathrm{S}_{1}=\frac{1+\Pi_{\mathrm{UTP}}}{1+\Pi_{\mathrm{USD}}} * \mathrm{~S}_{0} \quad$ which can be generalized as $S_{t+1}=\frac{1+\Pi_{\mathrm{UTP}}}{1+\Pi_{\mathrm{USD}}} * S_{t}$

To illustrate suppose at the end of 2017:

- the projected annual inflation rates for U.S. and Utopia are as follows:

$\begin{array}{lrrrrrrrrrr} & \mathbf{2 0 1 8} & \mathbf{2 0 1 9} & \mathbf{2 0 2 0} & \mathbf{2 0 2 1} & \mathbf{2 0 2 2} & \mathbf{2 0 2 3} & \mathbf{2 0 2 4} & \mathbf{2 0 2 5} & \mathbf{2 0 2 6} & \mathbf{2 0 2 7} \\ \text { US } & 2.13 & 2.61 & 2.40 & 2.21 & 2.30 & 2.24 & 2.24 & 2.24 & 2.24 & 2.24 \\ \text { Utopia } & 7.74 & 7.24 & 7.00 & 7.17 & 7.37 & 7.37 & 7.37 & 7.37 & 7.37 & 7.37\end{array}$

- and, the exchange rate UTP per USD was 15.00

Then the exchange rate in 2018 is expected to be $S_{1}=\frac{1.0213}{1.0774} * 15 \quad$ or 15.835

To determine the exchange rate for 2019, $S_{2}$, we use the derived figure for $S_{1}$, apply the generic equation (right hand side) as below, and the inflation projections for 2019:

$S_{2}=\frac{1+\Pi_{\mathrm{UTP}}}{1+\Pi_{\mathrm{USD}}} * S_{1}$

${ }^{49}$ For all market inputs, the AT requires projections for 10 years. However, in absence of such projections users should keep rates constant beyond the strategy period to allow the AT to generate debt service cash flows, required for cost-risk indicators that use cash flows until maturity of debt obligations. 
The exchange rates for years 2017 to 2027 using the inflation information above are:

$\begin{array}{llllllllllll} & 2017 & 2018 & 2019 & 2020 & 2021 & 2022 & 2023 & 2024 & 2025 & 2026 & 2027 \\ \text { UTP/USD } & 15.00 & 15.82 & 16.54 & 17.28 & 18.12 & 19.02 & 19.96 & 20.95 & 21.99 & 23.08 & 24.23\end{array}$

The analytical tool requires entries in form of depreciation (entered as positive number) or appreciation (as a negative number), which can be derived from the exchange rates above:

$\begin{array}{rrrrrrrrrrrr}\text { (Percent) } & 2017 & 2018 & 2019 & 2020 & 2021 & 2022 & 2023 & 2024 & 2025 & 2026 & 2027 \\ & 5.50 & 4.51 & 4.49 & 4.85 & 4.96 & 4.96 & 4.96 & 4.96 & 4.96 & 4.96 & 4.96\end{array}$

Note that PPP-based projections can be performed on a period-average or end-of-period basis. The latter is relevant to projecting the value of end of period stocks. 


\section{Annex L \\ Building a Domestic Yield Curve}

Users may need to derive a yield curve and forward yield curves to determine the borrowing cost of bonds, if such information is not readily available. This annex discusses one methodology that users can employ to derive a domestic yield curve; Annex $M$ discusses the derivation of forward yield curves. ${ }^{50}$

In absence of observable (and well established) domestic yields from which a yield curve can be constructed, users can build one by using the US Treasury yield curve as a starting point.

The Federal Reserve Board publishes Treasury yield curve estimates at a daily frequency (from 1961 to the present). The data is updated regularly with a 3-day lag; http://www.federalreserve.gov/pubs/feds/2006/200628/200628abs.html. The website provides par and zero-coupon yield curve data. ${ }^{51}$ The "Data- Excel file (30MB XLS)" contains daily yield curves, for maturities of 1 to 30 years, starting with zero coupon yield curve, columns, $B: A E$, labelled SVENY01 to SVENY30, followed by par yield curve, columns AF: BI, labelled SVENPY01 to SVENPY30.

To construct domestic yield curves for dates in the past, for example, say at end December 2017, the par yield curve can be a reference. Users should then add the sovereign credit spread, to derive the U.S. dollar yield curve for the country and inflation differential (exchange rate depreciation as set out in Annex $\mathrm{K}$ above) to determine the domestic yield curve. For countries that have issued an international sovereign bond recently, the sovereign credit spread can be inferred from the pricing of such bond (which often use the U.S. Treasury as a reference for pricing). In absence of such data, peers' credit spread can be applied.

To illustrate consider the following scenario:

Suppose Utopia's peer Dreamland had issued an international bond in USD of 10-year maturity on November 16, 2017 at a credit spread of 437 basis points (4.37 percent).

Using the information from the Federal Reserve Board website in the Data-Excel File, we find the par yield curve on November 16, 2017 (text chart). The 10-year rate was, 2.383 percent. By adding Dreamland's credit spread of $437 \mathrm{bps}$ to the 10 -year rate 238.3 bps we can estimate Utopia's cost of borrowing in USD in 2017 to be $675.3 \mathrm{bps}$.

\footnotetext{
${ }^{50}$ Please note this annex is not advocating for this particular methodology; indeed users that have other sources are encouraged to use those. The methodology is offered to assist those users that do not have alternatives. For simplicity, we assume all bonds pay coupon annually; see The US Treasury Yield Curve: 1961 to Present for methodology that considers bonds with semi-annual coupon payment.

${ }^{51}$ Yield to maturity rates are also available at https://www.federalreserve.gov/releases/h15/, which are updated daily.
} 
To derive the Utopia's cost borrowing for a 10-year domestic bond, we can add depreciation rate of 550 bps (see Annex K), bringing the 10 -year yield rate to $1225.3 \mathrm{bps}$.

The equations below summarize the methodology above:

- Let U.S. Treasury par yield curve with maturity $\mathrm{m}$ at time $\mathrm{t}$ be denoted by: $Y_{U S, t}^{m}$

- Let the credit spread of a country (Utopia in our case) for maturity $m$ at time t be: $\delta_{U T P, t}^{m}$

- Let the depreciation rate at time $\mathrm{t}$ be denoted by: $e_{t}$

Then:

- Utopia's cost of borrowing at time t for maturity m, in USD is given by:

$$
Y_{U S, t}^{m}+\delta_{U T P, t}^{m}
$$

That is, this is the coupon/interest rate on Utopia's 10-year USD bond.

- Utopia's cost of borrowing at time t for maturity m, in UTP is given by:

$$
Y_{U S, t}^{m}+\delta_{U T P, t}^{m}+e_{t}
$$

\section{That is, this is the coupon/interest rate on the 10-year Utopia bond.}

Please note that (a) credit spread information is likely to be sparse, with availability limited to a few maturities. The most common maturities for international bond issuance tend to be 5-year, 10-year, 15-year, and 20-year. As a result, users will have to either assume constant maturity across the yield curve or attempt to interpolate; and (b) users should consider adding liquidity premium to capture the difference in depth and liquidity between U.S. sovereign debt market and that of the country being analyzed. 


\section{Annex $\mathbf{M}^{52}$ \\ Forward Yield Curve}

Forward yield curves are built from zero coupon (or spot) yield curves, using the no arbitrage principle.

A forward interest rate can be denoted by $f(t, \tau, T)$, where:

- $t$ is the current time

- $\tau$ is the starting point of the forward contract, and

- $\mathrm{T}$ is the maturity of the contract.

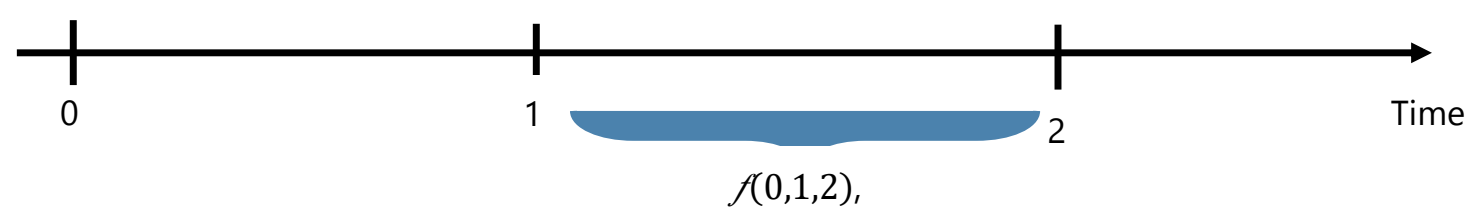

For example, $f(0,1,2)$ represents a contract today $(\mathrm{t}=0)$ to borrow for one year $(\mathrm{T}-\tau ; 2$ minus 1 ) in one-year time $(\tau)$.

The general formula is given by:

Equation (1)

$$
f(t, \tau, T)=\left[\frac{(1+Z(t, T))^{T-t}}{(1+Z(t, \tau))^{\tau-t}}\right]^{\frac{1}{T-\tau}}-1
$$

Where:

$Z(t, T)=$ represents the zero yield rates at time $t$ with maturity at $T$.

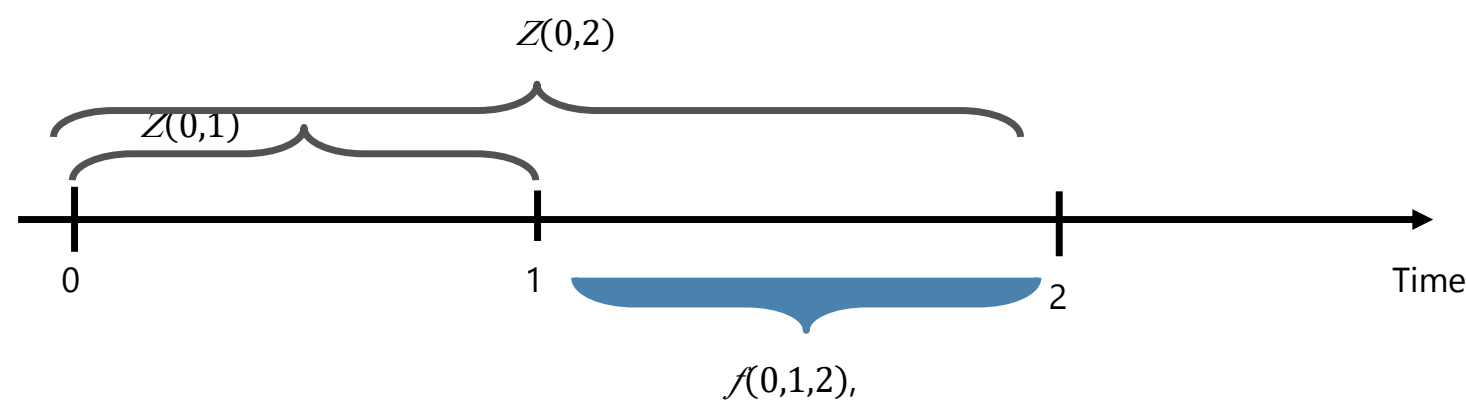

In an efficient market, with no arbitrage, investors should be indifferent between the decision to invest US\$1 today for two years or invest US\$1 today for one year and then invest the proceeds in one year.

Equation (2) $\quad f(0,1,2)=\left[\frac{(1+Z(0,2))^{2}}{(1+Z(0,1))^{1}}\right]^{1}-1$

For example, taking U.S. Treasury zero coupon rates at the end of December 2017 (December 29, 2017):

$$
\text { - } Z(0,2)=1.8852 \text { percent }
$$

\footnotetext{
52 Please note this annex is not advocating for this particular methodology; indeed, users that have other sources are encouraged to use those. The methodology is offered to assist those users that do not have alternatives. For simplicity, we assume all bonds pay coupon annually; see The US Treasury Yield Curve: 1961 to Present for methodology that considers bonds with semi-annual coupon payment.
} 
- $\quad Z(0,1)=1.7573$ percent

Based on this we can calculate the implied one-year zero-coupon forward rate, by plugging the two rates in Equation (2) above, which gives us: 2.013 percent.

Once the forward zero-coupon yield curves are constructed, users need to generate the par yield curves, since these are the ones used in the analytical tool. The step involves deriving discount factors from the spot rate which are applied to calculate the par yield curve. To illustrate taking the rates as at December 29, 2017:

\begin{tabular}{|c|c|c|c|c|}
\hline A & B & $\mathrm{C}$ & D & E \\
\hline laturity & Spot Rates & Discount Factors & Par Yield formula & Par Yield \\
\hline 1 & $\mathrm{Z}_{1}=1.7573$ & $d_{1}=\frac{1}{\left(1+Z_{1}\right)^{1}}=0.9827$ & $\begin{array}{c}1=C * d_{1}+1 * d_{1} \\
\frac{1-d_{1}}{d_{1}}=C\end{array}$ & 1.7573 \\
\hline 2 & $Z_{2}=1.8852$ & $d_{2}=\frac{1}{\left(1+Z_{2}\right)^{2}}=0.9633$ & $\begin{array}{c}1=C * d_{2} C * d_{1}+1 * d_{2} \\
\frac{1-d_{2}}{d_{1}+d_{2}}=C\end{array}$ & 1.8840 \\
\hline 3 & $Z_{2}=2.0033$ & $d_{3}=\frac{1}{\left(1+Z_{3}\right)^{3}}=0.9422$ & $\begin{array}{c}1=C^{*} d_{3}+C{ }^{*} d_{2}+C * d_{1}+1 * d_{3} \\
\frac{1-d_{3}}{d_{1}+d_{2}+d_{3}}=C\end{array}$ & 2.0001 \\
\hline
\end{tabular}

Note that zero-coupon yield curves can also be constructed from coupon bearing yield curves, for example, the par yield curve. Taking the par yield for maturities 1 and 2 on December 29, 2017.

A Maturity

1

2

$C_{2}=1.8926$

3
$F$

Par Yield*

$C_{1}=1.7647$

$C_{2}=1.8926$

$C_{3}=2.0098$
G

Discount Factors

$$
\begin{gathered}
1=C_{1} * d_{1}^{p}+1 * d_{1}^{p} \\
1=d_{1}^{p} *\left(1+C_{1}\right) \\
\frac{1}{\left(1+C_{1}\right)}=d_{1}^{P}
\end{gathered}
$$

$$
\begin{gathered}
1=C_{2}{ }^{*} d_{2}^{p}+C_{2}{ }^{*} d_{1}^{p}+1^{*} d_{2}^{p} \\
1=d_{2}^{P *}\left(C_{2}+1\right)+C_{2}{ }^{*} d_{1}^{p} \\
\frac{1-C_{2} * d_{1}^{P}}{1+C_{2}}=d_{2}^{P}
\end{gathered}
$$

$$
\begin{gathered}
1=C_{3}{ }^{*} d_{3}^{P}+C_{3}{ }^{*} d_{2}^{p}+C_{3}{ }^{*} d_{1}^{p}+1^{\star} d_{3}^{P} \\
1=d_{3}^{P *}\left(C_{3}+1\right)+C_{3} d_{2}^{p}+C_{3}{ }^{*} d_{1}^{p} \\
\\
\frac{1-C_{3} *\left(d_{1}^{P}+d_{2}^{P}\right)}{1+C_{3}}=d_{3}^{P}
\end{gathered}
$$

$\mathrm{H}$

Zero coupon

$d_{1}^{P}=\frac{1}{\left(1+Z_{1}\right)^{1}}$
$\frac{1}{d_{1}^{P}}=\left(1+z_{1}\right)^{1}$
$\frac{1}{d_{1}^{P}}-1=\left(Z_{1}\right)$

$d_{2}^{P}=\frac{1}{\left(1+Z_{2}\right)^{2}}$

$\frac{1}{d_{2}^{P}}=\left(1+Z_{2}\right)^{2}$

$\left(\frac{1}{d_{2}^{P}}\right)^{\frac{1}{2}}-1=Z_{2}$

$d_{3}^{P}=\frac{1}{\left(1+Z_{3}\right)^{3}}$

$\frac{1}{d_{3}^{P}}=\left(1+Z_{3}\right)^{3}$

$\left(\frac{1}{d_{3}^{P}}\right)^{\frac{1}{3}}-1=Z_{3}$
I

Zero coupon rate

1.7647

*Please note that the difference between the par yield rates derived in the table above (column E) compared to the ones from the U.S. Treasury website (column F) arise due to the assumption on frequency of coupon payments, annual in these illustrations versus semi-annual by the Federal Reserve. 


\section{Annex N \\ Formulae Used in the MTDS AT}

\begin{tabular}{|c|c|c|}
\hline \multicolumn{3}{|l|}{ CASH FLOW } \\
\hline Principal Repayment & $A_{t}^{D}=\frac{\text { Disbursement }_{0}}{\text { Maturity-Grace Period }}$ & $\begin{array}{l}\text { Where: } \\
A_{t}^{D}=\text { principal repayment or debt amortizing in } \\
\text { period t } \\
\text { Disbursement }_{0}=\text { Disbursement at time of } \\
\text { disbursement }\end{array}$ \\
\hline Outstanding Debt & $D_{t}=D_{t-1}+$ New $D_{t}-A_{t}^{D}$ & $\begin{array}{l}\text { Where: } \\
D_{t}=\text { debt outstanding at time } \mathrm{t} \\
D_{t-1}=\text { debt outstanding at time } \mathrm{t}-1 \\
\text { New } D_{t}=\text { New debt disbursed at time } \mathrm{t} \\
A_{t}^{D}=\text { principal repayment at time } \mathrm{t}\end{array}$ \\
\hline Outstanding Debt & $D_{t}=\sum_{t=1}^{T} A_{t}^{D}$ & $\begin{array}{l}\text { Where: } \\
D_{t}=\text { debt outstanding at time } \mathrm{t}\end{array}$ \\
\hline Fixed Interest Payments & $I_{t}^{F i x}=D_{t-1} * I R_{0}$ & $\begin{array}{l}\text { Where: } \\
I_{t}^{F i x}=\text { interest payments of fixed rate debt } \\
D_{t-1}=\text { debt outstanding at time } \mathrm{t}-1 \\
I R_{0}=\text { Interest rate set at the time of } \\
\text { disbursement }\end{array}$ \\
\hline Variable Interest Payments & $I_{t}^{V a r}=D_{t-1} * I R_{t-1}$ & $\begin{array}{l}\text { Where: } \\
I_{t}^{\text {Var }}=\text { interest payments of variable rate debt } \\
D_{t-1}=\text { debt outstanding at time } \mathrm{t}-1 \\
I R_{t-1}=\text { Interest rate at time } \mathrm{t}-1\end{array}$ \\
\hline Debt Service & $D S_{t}=A_{t}^{D}+I_{t}^{F i x}+I_{t}^{V a r}$ & $\begin{array}{l}\text { Where } \\
A_{t}^{D}=\text { principal repayment at time } \mathrm{t} \\
I_{t}^{\text {Fix }}=\text { interest payments of fixed rate debt } \\
I_{t}^{\text {Var }}=\text { interest payments of variable rate debt }\end{array}$ \\
\hline $\begin{array}{l}\text { Present Value of Debt } \\
\text { Service }\end{array}$ & $P V\left(D S_{t}\right)=\sum_{t=0}^{T} \frac{D S_{t+1}}{(1+\text { Discount Rate })^{t}}$ & \\
\hline
\end{tabular}




\begin{tabular}{|c|c|c|}
\hline \multicolumn{3}{|l|}{ COST - RISK INDICATORS } \\
\hline Nominal Debt to GDP & $\frac{D_{t}}{G D P_{t}}$ & $\begin{array}{l}\text { Where: } \\
D_{t}=\text { nominal Debt at time } \mathrm{t} \\
G D P_{t}=\text { nominal GDP at time } \mathrm{t}\end{array}$ \\
\hline $\begin{array}{l}\text { Present Value of Debt to } \\
\text { GDP }\end{array}$ & $\frac{P V\left(D S_{t}\right)}{G D P_{t}}$ & $\begin{array}{l}\text { Where: } \\
\begin{aligned} P V(D S)_{t} & =\text { Present value of debt service } \\
& =\text { Present value of debt }\end{aligned}\end{array}$ \\
\hline \multicolumn{3}{|l|}{ Cost of Debt } \\
\hline Interest cost & $I_{t}^{*}=\sum_{j=1}^{m} I_{t}^{D X}+e_{j t} t_{j t}^{F X}$ & $\begin{array}{l}\text { Where: } \\
I_{t}^{*}=\text { interest payments in domestic currency at } \\
\text { time } t \\
e_{j t}=j^{\text {th }} \text { exchange rate between the domestic } \\
\text { currency and foreign currency } j \\
I_{j t}^{F X}=\text { interest payments denominated in foreign } \\
\text { currency } j \\
I_{t}^{D X}=\text { interest payments denominated in } \\
\text { domestic currency }\end{array}$ \\
\hline Interest Payments to GDP & $I_{t}^{G D P}=\frac{I_{t}^{*}}{G D P_{t}}$ & $\begin{array}{l}\text { Where: } \\
G D P_{t}=\text { nominal GDP at time } \mathrm{t}\end{array}$ \\
\hline $\begin{array}{l}\text { Interest Payments to } \\
\text { Revenue }\end{array}$ & $I_{t}^{\text {Revenue }}=\frac{I_{t}^{*}}{\text { Revenue }_{t}}$ & $\begin{array}{l}\text { Where: } \\
\text { Revenue }_{t}=\text { nominal revenue at time } \mathrm{t}\end{array}$ \\
\hline $\begin{array}{l}\text { Average (unweighted) } \\
\text { interest rate }\end{array}$ & $\begin{array}{c}\quad \overline{l_{t}}=\frac{I_{t}^{*}}{D_{t}} \\
=\frac{\sum_{j=1}^{m} I_{t}^{D X}+e_{j t} I_{j t}^{F X}}{D_{t}^{D X}+D_{t}^{F X}} \\
=\frac{\sum_{j=1}^{m} I_{t}^{D X}+e_{j t} I_{j t}^{F X}}{D_{t}^{D X}+\sum_{j=1}^{m} e_{t, j} D_{t, j}^{F X}}\end{array}$ & $\begin{array}{l}\text { Where: } \\
D_{t}^{D X}=\text { outstanding domestic currency debt } \\
D_{t}^{F X}=\sum_{j=1}^{m} e_{t, j} D_{t, j}^{F X}=\text { outstanding foreign } \\
\text { currency debt converted into domestic currency }\end{array}$ \\
\hline $\begin{array}{l}\text { Weighted Average of } \\
\text { Interest Rate }\end{array}$ & $\overline{\omega l_{t}}=\frac{\prod_{k=1}^{n} I R_{k, t} \cdot B_{k, t}}{\sum_{k=1}^{n} B_{k, t}}$ & $\begin{array}{l}\text { Where: } \\
I R_{k}=\text { Interest rate for each borrowing } \\
\text { instrument at time } \mathrm{t} \\
B_{k}=\text { outstanding debt for each borrowing } \\
\text { instrument at time } \mathrm{t} \\
D_{t}=\sum_{k=1}^{n} B_{k, t}=\text { total debt outstanding }\end{array}$ \\
\hline $\begin{array}{l}\text { Interest cost adjusted for } \\
\text { capital gains/losses on } \\
\text { indexed debt } / 1\end{array}$ & $C_{t}^{*}=I_{t}^{*}+\sum_{j=1}^{m}\left(D_{t-1, j}^{F X} \Delta e_{t, j}\right)$ & $\begin{array}{l}\text { Where: } \\
\sum_{j=1}^{m}\left(D_{t-1, j}^{F X} \Delta e_{t, j}\right)=\text { the capital gains/losses } \\
\text { arising from the change in the exchange rates } \\
\text { associated with outstanding FX debt at } t-1\end{array}$ \\
\hline
\end{tabular}




\begin{tabular}{|c|c|c|}
\hline Refinancing Risk & & \\
\hline $\begin{array}{l}\text { Debt Maturing within a } \\
\text { particular Year as a } \\
\text { percentage of total }\end{array}$ & $\frac{A_{t}^{D}}{D_{t}}$ & $\begin{array}{l}\text { Where: } \\
A_{t}^{D}=\text { debt amortizing at time } \mathrm{t} \\
D_{t}=\text { total debt portfolio }\end{array}$ \\
\hline $\begin{array}{l}\text { Debt Maturing within a } \\
\text { particular Year as a } \\
\text { percentage of GDP }\end{array}$ & $\frac{A_{t}^{D}}{G D P_{t}}$ & $\begin{array}{l}\text { Where: } \\
A_{t}^{D}=\text { debt amortizing at time } \mathrm{t} \\
G D P_{t}=\text { nominal GDP at time } \mathrm{t}\end{array}$ \\
\hline Refinancing (roll-over) risk & $\begin{aligned} & R P_{t}= {\left[A_{t}\right]_{t=1}^{T}=\left[A_{t}^{D X}+A_{t}^{F X}\right]_{t=1}^{T} } \\
&=\left[A_{t}^{D X}+\sum_{j=1}^{m}\left(A_{t, j}^{F X} \cdot e_{t, j}\right)\right]_{t=1}^{T} \\
&=\left\{A_{1}, A_{2}, \ldots, A_{t=T}\right\}\end{aligned}$ & $\begin{array}{l}\text { Where: } \\
R P_{t}=\text { the redemption profile } \\
A_{t}^{D X}=\text { principal repayments on domestic debt } \\
\text { falling in period } \mathrm{t} \\
A_{t}^{F X}=\sum_{j=1}^{m} e_{t, j} A_{t, j}^{f, F X}=\text { principal repayments on } \\
\text { foreign currency denominated debt falling due } \\
\text { in that period (converted into domestic } \\
\text { currency) }\end{array}$ \\
\hline $\begin{array}{l}\text { Average Time to Maturity } \\
\text { (Years) }\end{array}$ & $A T M_{t}=\frac{\sum_{t=1}^{T}\left(A_{t} \cdot t\right)}{\sum_{t=1}^{T} A_{t}}$ & $\begin{array}{l}\text { Where: } \\
A_{t}=\mathrm{t}^{\text {th }} \text { period principal payment in the } \\
\text { portfolio }\end{array}$ \\
\hline \multicolumn{3}{|l|}{ Interest Rate Risk } \\
\hline $\begin{array}{l}\text { Average Time to Re-fixing } \\
\text { (Years) }\end{array}$ & $A T R_{t}=\frac{\omega^{f} \cdot \sum_{t=1}^{T}\left(A_{t}^{f} \cdot t\right)+\omega^{v} \cdot \sum_{s=1}^{S}\left(D_{t, s}^{v} \cdot S\right)}{D_{t}}$ & $\begin{array}{l}\text { Where: } \\
S=\text { time to the next interest rate reset for the } \\
\text { variable rate debt } \\
\omega^{f} \text { and } \omega^{v}=\text { are the respective shares of the } \\
\text { fixed rate principal falling due and variable rate } \\
\text { debt outstanding }\end{array}$ \\
\hline $\begin{array}{l}\text { Debt Re-fixing in a } \\
\text { particular year }\end{array}$ & $\begin{array}{c}D_{t}^{r e f i x}=D^{v}+A_{t}^{f}= \\
D^{v, F X}+D^{v, D X}+A_{t}^{f, D X}+A_{t}^{f, F X}\end{array}$ & $\begin{array}{l}\text { Where: } \\
D^{v}=D^{v, F X}+D^{v, D X}=\text { total variable debt } \\
D^{v, F X}=\sum_{j=1}^{m} e_{j} D_{j}^{v, F X}=\text { total foreign currency } \\
\text { denominated variable debt converted into } \\
\text { domestic currency } \\
D^{v, D X}=\text { total domestic currency variable rate } \\
\text { debt } \\
A_{t}^{f, D X}=\text { principal repayments on domestic } \\
\text { fixed-rate debt falling due in that year } \\
A_{t}^{f, F X}=\sum_{j=1}^{m} e_{t, j} A_{t, j}^{f, F X}=\text { principal repayments on } \\
\text { foreign currency denominated fixed rate debt } \\
\text { falling due in that year (converted into domestic } \\
\text { currency) }\end{array}$ \\
\hline $\begin{array}{l}\text { Debt re-fixing as a Percent } \\
\text { of Total }\end{array}$ & $d_{t}^{r e f i x}=\frac{D_{t}^{r e f i x}}{D_{t}}$ & $\begin{array}{l}\text { Where: } \\
D_{t}=\text { total debt portfolio }\end{array}$ \\
\hline $\begin{array}{l}\text { T-bills as a Percent of } \\
\text { Total }\end{array}$ & $d_{T-\text { bills }}=\frac{D_{T-\text { bills }}}{D_{t}}$ & $\begin{array}{l}\text { Where: } \\
D_{T-\text { bills }}=\text { total outstanding T-bills }\end{array}$ \\
\hline
\end{tabular}




\begin{tabular}{|c|c|c|}
\hline Exchange Rate Risk & & \\
\hline $\begin{array}{l}\text { Foreign Currency Debt } \\
\text { (Percent of Total Debt) }\end{array}$ & $\begin{array}{c}d_{t}^{f x}=\frac{D_{t}^{F X}}{D_{t}}=\frac{D_{t}^{F X}}{D_{t}^{D X}+D_{t}^{F X}}= \\
\frac{\sum_{j=1}^{m} e_{t, j} \cdot D_{t, j}^{F X}}{D_{t}^{D X}+\sum_{j=1}^{m} e_{t, j} \cdot D_{t, j}^{F X}}\end{array}$ & $\begin{array}{l}\text { Where: } \\
D_{t}^{F X}=\text { total debt outstanding denominated in } \\
\text { foreign currency (converted into domestic } \\
\text { currency) }\end{array}$ \\
\hline $\begin{array}{l}\text { Short-term Foreign } \\
\text { Currency Debt (Percentage } \\
\text { of Reserves) }\end{array}$ & $d_{S T}^{f x}=\frac{D_{S T}^{F X}}{\text { Foreign Curreny Reserves } \text { st }_{t}}$ & $\begin{array}{l}\text { Where: } \\
D_{S T}^{F X}=\text { foreign currency debt maturing in the } \\
\text { next period } \\
\text { Note: both short-term foreign currency debt and } \\
\text { foreign currency reserves need to be expressed in the } \\
\text { same currency }\end{array}$ \\
\hline
\end{tabular}




\section{Annex 0 \\ Excel Macros and Functions Used in the MTDS AT}

\begin{tabular}{|c|c|}
\hline Name & Purpose \\
\hline \multicolumn{2}{|l|}{ Excel Macros } \\
\hline Protect_Sheets & $\begin{array}{l}\text { Protects worksheets: } \\
\text { - New_Debt (Original Currency } \\
\text { - New_Debt (Domestic Currency) } \\
\text { - Total_Debt }\end{array}$ \\
\hline Unprotect_Sheets & Unprotects the protected worksheets by "Protect_Sheets" \\
\hline HideCalculationSheets & $\begin{array}{l}\text { Hides worksheets: } \\
\text { - Strategy 1, Strategy 2, Strategy 3, and Strategy } 4 \\
\text { - New_Debt (Original Currency } \\
\text { - New_Debt (Domestic Currency) } \\
\text { - } \quad \text { Total_Debt }\end{array}$ \\
\hline UnhideCalculationSheets & $\begin{array}{l}\text { Unhides the worksheets hidden by "HideCalculationSheets" Excel- } \\
\text { Macro }\end{array}$ \\
\hline HideVisualMap & Hides worksheets Input Visual Map and List of Outputs \\
\hline UnhideVisualMap & Unhides the worksheets hidden by HideVisualMap \\
\hline HighlightInputAreas & $\begin{array}{l}\text { Highlights the input areas in worksheets, Macro and Market Data } \\
\text { and Strategy as stipulated by the strategy horizon; and turns all } \\
\text { ATR and ATM calculations to blank for years below and outside } \\
\text { the strategy horizon year. }\end{array}$ \\
\hline Initialize_only & $\begin{array}{l}\text { Runs all strategies based on baseline assumptions only (i.e., } \\
\text { excluding shock scenarios). }\end{array}$ \\
\hline Run_all_strategies & Runs all strategies under all shock scenarios and baseline. \\
\hline Run_Strategy1 & Runs strategy 1 only for baseline and shock scenarios. \\
\hline Run_Strategy2 & Runs strategy 2 only for baseline and shock scenarios \\
\hline Run_Strategy3 & Runs strategy 3 only for baseline and shock scenarios \\
\hline Run_Strategy4 & Runs strategy 4 only for baseline and shock scenarios \\
\hline Strategy1_only & Used in Run_Strategy1 Excel Macro \\
\hline Strategy2_only & Used in Run_Strategy2 Excel Macro \\
\hline Strategy3_only & Used in Run_Strategy3 Excel Macro \\
\hline Strategy4_only & Used in Run_Strategy4 Excel Macro \\
\hline \multicolumn{2}{|l|}{ Functions } \\
\hline Data Validation (Error Alert) & $\begin{array}{l}\text { Used to prevent entering negative cash buffer in the Strategy } \\
\text { worksheet. }\end{array}$ \\
\hline
\end{tabular}


TNM/18/XX

International Monetary Fund
Monetary and Capital Markets Department

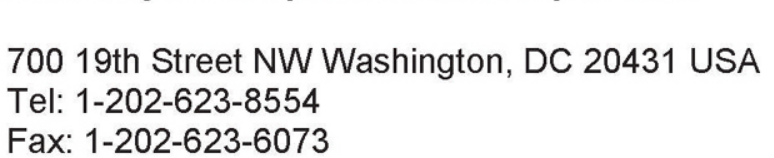

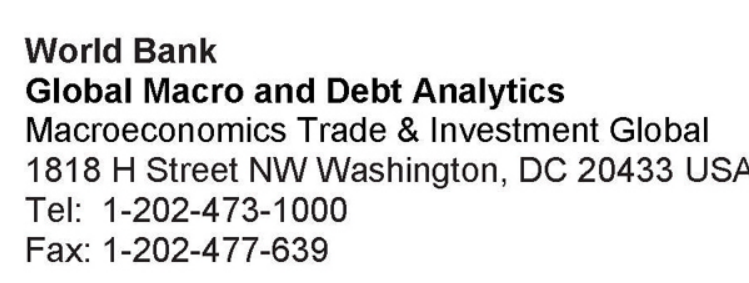

